\title{
Pathways from marine protected area design and management to ecological success
}

Murray A Rudd

Using an international dataset compiled from 121 sites in 87 marine protected areas (MPAs) globally (Edgar et al., 2014), I assessed how various configurations of design and management conditions affected MPA ecological performance, measured in terms of fish species richness and biomass. The set-theoretic approach used Boolean algebra to identify pathways that combined up to five 'NEOLI' (No-take, Enforced, Old, Large, Isolated) conditions and that were sufficient for achieving positive, and negative, ecological outcomes. Ecological isolation was overwhelming the most important condition affecting ecological outcomes but Old and Large were also conditions important for achieving high levels of biomass among large fishes (jacks, groupers, sharks). Solution coverage was uniformly low $(<0.35)$ for all models of positive ecological performance suggesting the presence of numerous other conditions and pathways to ecological success that did not involve the NEOLI conditions. Solution coverage was higher $(>0.50)$ for negative results (i.e., the absence of high biomass) among the large commercially-exploited fishes, implying asymmetries in how MPAs may rebuild populations on the one hand and, on the other, protect against further decline. The results revealed complex interactions involving MPA design, implementation, and management conditions that affect MPA ecological performance. In general terms, the presence of no-take regulations and effective enforcement were insufficient to ensure MPA effectiveness on their own. Given the central role of ecological isolation in securing ecological benefits from MPAs, site selection in the design phase appears critical for success. 
1 Pathways from marine protected area design and management to ecological success

2

3

4

\author{
Murray A. Rudd \\ Department of Environment Sciences, Emory University \\ Math and Science Center, $5^{\text {th }}$ Floor, 400 Dowman Drive, \\ Atlanta, Georgia 30322, USA \\ Email: murray.a.rudd@emory.edu \\ Phone: 404-727-3262 \\ Fax: 404-727-4448
}




\section{Abstract}

Using an international dataset compiled from 121 sites in 87 marine protected areas

management conditions affected MPA ecological performance, measured in terms of fish species richness and biomass. The set-theoretic approach used Boolean algebra to identify pathways that combined up to five 'NEOLI' (No-take, Enforced, Old, Large, Isolated) conditions and that were sufficient for achieving positive, and negative, ecological outcomes. Ecological isolation was overwhelming the most important condition affecting ecological outcomes but Old and Large were also conditions important for achieving high levels of biomass among large fishes (jacks, groupers, sharks). Solution coverage was uniformly low $(<0.35)$ for all models of positive ecological performance suggesting the presence of other conditions and pathways to ecological success that did not involve the NEOLI conditions. Solution coverage was higher $(>0.50)$ for negative results (i.e., the absence of high biomass) among the large commercially-exploited fishes, implying asymmetries in how MPAs may rebuild populations on the one hand and, on the other, protect against further decline. The results revealed complex interactions involving MPA design, implementation, and management conditions that affect MPA ecological performance. The presence of no-take regulations and effective enforcement were on their own generally not sufficient to ensure positive MPA outcomes. Given the central role of ecological isolation in securing ecological benefits from MPAs, site selection in the design phase appears critical for success. 


\section{Introduction}

In the face of multiple pressures on marine ecosystems and resources, the creation of marine protected areas (MPAs) has been advanced as a robust management approach for conserving aquatic ecosystems and habitats, and maintaining ecological resilience (Allison et al., 2003; Lubchenco et al., 2003; Roberts, 1997). MPAs may help maintain ecological connectivity, protect critical habitat, provide a refuge for commercial and threatened species, and increase the viability of adjacent fisheries over the long-term (Gell and Roberts, 2003; Halpern and Warner, 2002; Lester et al., 2009; Sumaila et al., 2000; Weigel et al., 2014). There has been increasing recognition and appreciation of the potential importance of the ecological, social, and political context within which MPAs are designed and implemented (Crawford et al., 2006; Huijbers et al., 2015; Pollnac et al., 2001; Rudd et al., 2003; Soykan and Lewison, 2015; Vandeperre et al., 2011; Warner and Pomeroy, 2012). Even after two decades of intensive ecology and modeling (Lester et al., 2009; White et al., 2011), however, understanding the role that MPAs play in ameliorating multiple stressors and in the provision of benefits to humans remains an important international research priority (Parsons et al., 2014; Rudd, 2014).

Given broad and potentially conflicting goals for MPAs (Agardy et al. 2003; Brown et al. 2001; Jones 2002) and the range and complexity of factors interacting to affect MPA performance (e.g., Edgar et al. 2014; Guidetti and Sala 2007; Soykan and Lewison 2015), it seems highly probable that multiple context-dependent pathways to 'success' exist. Empirical MPA studies typically focus on short-term ecological outcomes at limited scales, while MPA models are typically more abstract, focusing on ecological responses arising from MPAs over larger spatial and temporal scales (White et al., 2011). As Halpern (2014: 167) noted, however, while it may seem "we know a lot about what leads to MPA success or failure... the 
62 simultaneous assessment of how various factors affect MPA success has been missing ..." This

63 is especially the case when the design, governance, and management attributes of MPAs are

64 considered in conjunction with ecological factors.

65 Statistical analysis of the causal relationships between MPA design, management, and

66 outcomes can be problematic when limited number of case studies are available, making it

67 difficult to identify pathways from MPA design and management to ecological outcomes.

68 Developments over the last 20 years in set-theoretic approaches for comparative case analysis now, however, offer an approach with which to analyze contextual complexity in small- and medium-n comparative studies. This configuration-oriented approach, commonly referred to as qualitative comparative analysis (QCA), explores connections between causally relevant conditions and outcomes using set theory (Goertz and Mahoney 2012; Ragin 1987; Schneider and Wagemann 2012). Cases are defined in terms of sets, combinations of conditions and outcomes, and Boolean algebra is used to simplify logical statements describing how those combinations are related to relevant outcomes. Set-theoretic methodologies have become increasingly popular in the social sciences for assessing contextual complexity (Rihoux 2013; Rihoux and Marx 2013; Schneider and Wagemann 2012) but their use has been relatively limited in fisheries and marine conservation research (but see Bodin and Österblom 2013; Kosamu 2015; Stokke 2007; Sutton and Rudd 2015).

In their global MPA analysis, Edgar et al. (2014) aggregated some 171,000 underwater abundance counts from Reef Life Survey scuba transect data collected from 964 sites in 87 international MPAs, and combined them in 121 international MPA/ecoregion groupings. Their analytical focus was on the influence of NEOLI (No-take, Enforced, Old, Large, Isolated) conditions on fish biomass and fish species richness. Their statistical analysis (Edgar et al. 2014: 
85 216) suggested that the conservation benefits of MPAs "increase exponentially with the

86 accumulation of the five key features: no take, well enforced, old ( $>10$ years), large ( $>100 \mathrm{~km} 2)$,

87 and isolated by deep water or sand" (as one reviewer pointed out, however, the exponential

88 pattern was in back-transformed log response ratios of inside versus outside biomass, so results could be amplified). That dataset provides an opportunity to use a set-theoretic approach to test

90 for context-dependent pathways from MPA design and management conditions to positive (and

91 negative) ecological performance. My research questions were: (1) what combinations of NEOLI

92 features interact to affect ecological performance metrics in MPAs? and (2) how do pathways to

93 positive and negative MPA outcomes vary for different ecological performance metrics?

\section{Methods}

96

\section{Data}

The global MPA dataset contained information from 964 sites in 87 MPAs, which was aggregated into $121 \mathrm{MPA}$ /ecoregion groupings (hereafter referred to simply as MPAs for simplicity) for analysis. Edgar and Stuart-Smith (2009) provide details on Reef Life survey methodology and Edgar et al. (2014) provide additional information about global survey procedures and data compilation. Their dataset is based on transects performed by trained volunteer scuba divers and represents in excess of 171,000 underwater abundance counts at 1,986 dive sites (Edgar et al. 2014).

\section{Data analysis}

\section{Qualitative Comparative Analysis}


present, are necessary or sufficient to lead to outcomes of interest (Ragin 1987; Ragin 2000;

Schneider and Wagemann 2012). Each case (i.e., one of 121 MPAs in this analysis) is considered

111 as a configuration of causally relevant conditions (i.e., combinations of the presence or absence

112 of NEOLI conditions) and an outcome (i.e., metrics of fish biomass or species richness). QCA

113 comparatively identifies similarities and differences across cases where different, context-

114 dependent paths lead to particular outcomes of interest (Rihoux 2013). Boolean minimization

115 algorithms in QCA software (Ragin and Davey 2014) succinctly express causal regularities in

116 the data. Results from analyses are contextual in that the causal power of a condition often

117 depends on the presence of absence of other causal conditions.

118 To illustrate how QCA can provide information regarding pathways to successful

119 ecological outcomes, consider how contextual social and governance factors influence ecological

120 success in small-scale fisheries in Southeast Asia (Sutton and Rudd, 2015). Among 50 case

121 studies, multiple pathways involving various combinations of social and governance conditions

122 led to local ecological successes, defined on a scale from extremely degraded to thriving local

123 fish stocks. One pathway to success involved the presence of a community organization involved

124 in community-based fisheries management in combination with a degree of autonomy in local

125 governance decision-making at the community level. A second pathway to positive ecological

126 results arose when local fisheries were subsistence oriented, even in the absence of local

127 decision-making powers. Another pathway involved strong local leadership: even with weak

128 local decision-making powers and a market-oriented local fishery, positive ecological outcomes

129 were observed, suggesting local leadership could help mobilize a degree of restraint in local 
130 fisheries that helped ameliorate some external stressors. Together these three alternative

131 pathways accounted for $69 \%$ of cases where successful ecological outcomes were attained.

132

Data coding

Case conditions and outcomes may be coded as dichotomous 'crisp sets' that dichotomously classify variables as 0 or 1 (fully out of or in a set) or as 'fuzzy sets' that exhibit

136 partial membership in the set of an ideal type (Ragin 2000). Edgar et al. (2014) originally coded

137 the NEOLI conditions into low-medium-high categories for each variable. As the most important differences in their study was between medium and high levels of NEOLI conditions (see Figure 3, Edgar et al. 2014), and conditions in the middle of a scale provide no additional information useful for differentiating sets in QCA (membership of 50\% in a condition's set is the point of maximum ambiguity in QCA), I aggregated low and medium levels to form crisp set definitions of NEOLI conditions (Table 1). Each condition was thus either fully in or fully out as a member results and prior to any QCA data analysis.

146 Table 1- Number of MPAs belonging to NEOLI condition sets

$$
\text { Edgar et al. coding Crisp sets }
$$

\begin{tabular}{|c|c|c|c|c|c|c|}
\hline Condition & Low & Med & High & Fully Out & Fully In & Comments \\
\hline No-take & 0 & 46 & 75 & 46 & 75 & $\begin{array}{l}\text { Referred to as governance or regulations by Edgar } \\
\text { et al. (2014): low=openly fished; med=within MPA } \\
\text { but with some fishing; high=no-take zone within } \\
\text { MPA }\end{array}$ \\
\hline Enforced & 12 & 27 & 82 & 39 & 82 & $\begin{array}{l}\text { Assessed by field survey teams (Edgar et al., 2014): } \\
\text { low='paper park' with little control; med=moderate } \\
\text { policing but with violations; high=well-enforced }\end{array}$ \\
\hline Old & 19 & 38 & 64 & 57 & 64 & Low $=<5$ yrs; Med=5-10 yrs; High $>10$ yrs \\
\hline Large & 24 & 56 & 41 & 80 & 41 & Low $=<1 \mathrm{~km}^{2} ;$ Med $=1-100 \mathrm{~km}^{2} ; \mathrm{High}>100 \mathrm{~km}^{2}$ \\
\hline
\end{tabular}




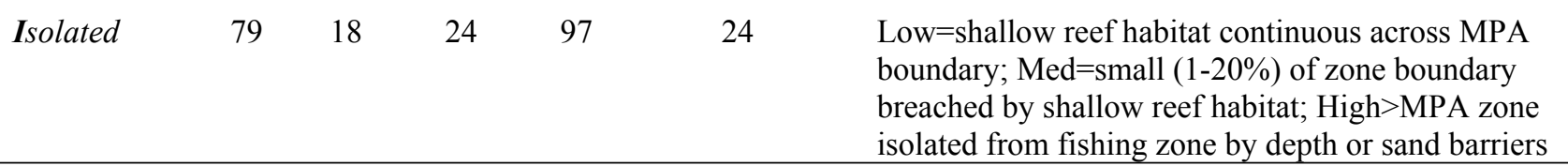

147

148

149

150

151

152

153

154

155

156

157

158

159

160

161

162

163

All ecological outcomes in the Edgar et al. (2014) dataset were measured during reef scuba surveys as biomass or fish species richness per $250 \mathrm{~m}^{2}$. I log-transformed $(\ln [n+1])$ them to fuzzy set membership values in a calibration process. If fish species richness or biomass exceeded the $90^{\text {th }}$ percentile for that outcome across all 121 MPAs, they were considered fully in that condition's set of successful outcomes; if fish species richness or biomass was less than the $10^{\text {th }}$ percentile, they were considered fully out of the set (Table 2). The crossover was the point where an MPA with an overall fish biomass level of 14,765 g per $250 \mathrm{~m}^{2}$ would, for example, be assigned 0.50 membership in the set High biomass (and by implication 0.50 in a set NOT/High biomass]). There are no theoretical reasons for defining 'high' levels of outcomes at particular levels but some MPAs within the Reef Life Survey dataset were functionally pristine, so full set membership in a positive outcome (i.e., $>90^{\text {th }}$ percentile for that condition) should indicate performance that is truly high in the range of possibilities. Note that a biomass of $120,572 \mathrm{~g}$ per $250 \mathrm{~m}^{2}$ corresponds to approximately $4,800 \mathrm{~kg}$ per ha, a figure well in excess of values suggested as baselines to define pristine reef fish biomass (MacNeil et al. 2015).

Table 2 - Summary of outcome set calibrations

\begin{tabular}{|c|c|c|c|c|c|c|c|}
\hline \multirow[b]{2}{*}{ Outcome sets } & \multirow[b]{2}{*}{ Min } & \multirow[b]{2}{*}{ Mean } & \multirow[b]{2}{*}{ Max } & \multicolumn{3}{|c|}{ Fuzzy membership calibration } & \multirow[b]{2}{*}{$\ln (n+1)\left(\right.$ per $\left.250 \mathrm{~m}^{2}\right)$} \\
\hline & & & & Fully out & Crossover & Fully in & \\
\hline High biomass & 4.07 & 9.78 & 12.38 & $\begin{array}{l}7.5 \\
(1808)^{*}\end{array}$ & $\begin{array}{l}9.6 \\
(14765)\end{array}$ & $\begin{array}{l}11.7 \\
(120572)\end{array}$ & total fish biomass [g] \\
\hline $\begin{array}{l}\text { High large fish } \\
\text { biomass }\end{array}$ & 3.11 & 8.54 & 11.79 & $\begin{array}{l}5.5 \\
(245)\end{array}$ & $\begin{array}{l}8.1 \\
(3295)\end{array}$ & $\begin{array}{l}10.7 \\
(44356)\end{array}$ & $\begin{array}{l}\text { total biomass }[\mathrm{g}] \text { of large } \\
\text { fish }\end{array}$ \\
\hline $\begin{array}{l}\text { High damselfish } \\
\text { biomass }\end{array}$ & 0.00 & 6.46 & 11.05 & $\begin{array}{l}3.5 \\
(33)\end{array}$ & $\begin{array}{l}6.4 \\
(602)\end{array}$ & $\begin{array}{l}9.3 \\
(10938)\end{array}$ & $\begin{array}{l}\text { total biomass }[\mathrm{g}] \text { of } \\
\text { damselfish }\end{array}$ \\
\hline $\begin{array}{l}\text { High grouper } \\
\text { biomass }\end{array}$ & 0.00 & 3.36 & 8.74 & $\begin{array}{l}1.0 \\
(3)\end{array}$ & $\begin{array}{l}4.5 \\
(90)\end{array}$ & $\begin{array}{l}8.0 \\
(2981)\end{array}$ & $\begin{array}{l}\text { total biomass }[\mathrm{g}] \text { of } \\
\text { groupers }\end{array}$ \\
\hline $\begin{array}{l}\text { High jack } \\
\text { biomass }\end{array}$ & 0.00 & 3.89 & 10.93 & $\begin{array}{l}3.0 \\
(20)\end{array}$ & $\begin{array}{l}6.3 \\
(518)\end{array}$ & $\begin{array}{l}9.5 \\
(13360)\end{array}$ & total biomass $[\mathrm{g}]$ of jacks \\
\hline
\end{tabular}




$\begin{array}{llllllll}\begin{array}{l}\text { High shark } \\ \text { biomass }\end{array} & 0.00 & 2.78 & 11.06 & \begin{array}{l}0.7 \\ (2)\end{array} & \begin{array}{l}5.1 \\ (164)\end{array} & \begin{array}{l}9.5 \\ (13360)\end{array} & \text { total biomass [g] of sharks } \\ \begin{array}{l}\text { High fish species } \\ \text { richness }\end{array} & 0.77 & 2.79 & 4.12 & \begin{array}{l}1.5 \\ (5)\end{array} & \begin{array}{l}2.7 \\ (14)\end{array} & \begin{array}{l}3.8 \\ (45)\end{array} & \text { all fish species } \\ \begin{array}{l}\text { High large fish } \\ \text { species richness }\end{array} & 0.04 & 1.27 & 2.39 & \begin{array}{l}0.2 \\ (1)\end{array} & \begin{array}{l}1.1 \\ (3)\end{array} & \begin{array}{l}1.9 \\ (7)\end{array} & \begin{array}{l}\text { large fish }[>300 \mathrm{~mm}] \\ \text { species }\end{array} \\ \begin{array}{l}\text { * values in parentheses denote cut-off and cross-over biomass and species richness values prior to } \ln (n+1) \\ \text { transformation }\end{array}\end{array}$

$164 *$ values in parent

166

168 indistinguishable from fished sites (Edgar et al. 2014). The lower $10^{\text {th }}$ percentile cut-off that

169 defined outcomes as fully outside the set of successful outcomes should thus reflect truly poor

170 levels of MPA performance. Table 3 details the coding for each MPA (starting with MPAs

171 exhibiting all five NEOLI conditions at the top of the table, proceeding through groupings of

172 MPAs with decreasing numbers of NEOLI conditions, and ending with those MPAs that had

173 only a single NEOLI condition). 


\begin{tabular}{|c|c|c|c|c|c|c|c|c|c|c|c|c|c|c|}
\hline & Country & 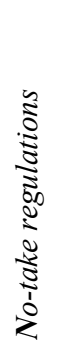 & 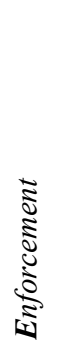 & 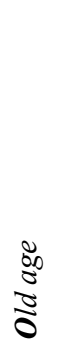 & 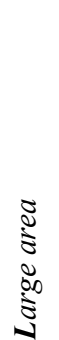 & 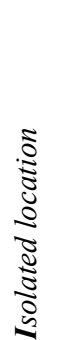 & 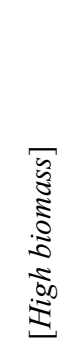 & 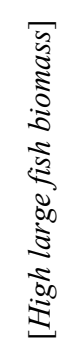 & 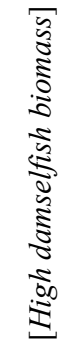 & 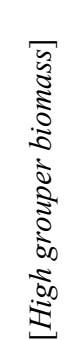 & 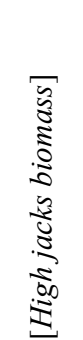 & 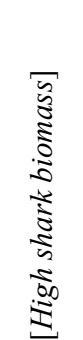 & 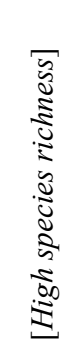 & 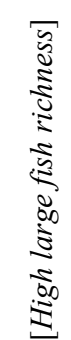 \\
\hline 15. Cocos National Park & Costa Rica & 1 & 1 & 1 & 1 & 1 & 0.98 & 1.00 & 0.78 & 0.80 & 0.91 & 1.00 & 0.74 & 1.00 \\
\hline 34. Kermadec Marine Reserve & New Zealand & 1 & 1 & 1 & 1 & 1 & 0.99 & 1.00 & 0.98 & 0.93 & 0.77 & 1.00 & 0.60 & 0.95 \\
\hline 37. Lord Howe Commonwealth MPA a & Australia & 1 & 1 & 1 & 1 & 1 & 0.78 & 0.96 & 0.78 & 0.95 & 0.70 & 1.00 & 0.75 & 0.91 \\
\hline 40. Malpelo Flora and Fauna Sanctuary & Colombia & 1 & 1 & 1 & 1 & 1 & 0.99 & 1.00 & 0.89 & 1.00 & 0.76 & 1.00 & 0.64 & 0.93 \\
\hline 20. Florida Keys National Marine Sanctuary b & United States & 1 & 1 & 1 & 1 & 0 & 0.73 & 0.68 & 0.76 & 0.69 & 0.89 & 0.00 & 0.71 & 0.85 \\
\hline 72. Tsitsikamma National Park & South Africa & 1 & 1 & 1 & 1 & 0 & 0.65 & 0.62 & 0.00 & 0.58 & 0.00 & 0.00 & 0.33 & 0.69 \\
\hline 52. Poor Knights Island Marine Reserve & New Zealand & 1 & 1 & 1 & 0 & 1 & 0.65 & 0.71 & 1.00 & 0.00 & 0.79 & 0.00 & 0.39 & 0.73 \\
\hline 63. Shiprock Aquatic Reserve & Australia & 1 & 1 & 1 & 0 & 1 & 0.88 & 0.88 & 0.52 & 0.73 & 0.86 & 0.00 & 0.90 & 1.00 \\
\hline 1. Aldinga Reef & Australia & 1 & 1 & 1 & 0 & 0 & 0.40 & 0.63 & 0.23 & 0.00 & 0.00 & 0.00 & 0.44 & 0.56 \\
\hline 11. Cape Rodney to Okakari Point Marine Reserve & New Zealand & 1 & 1 & 1 & 0 & 0 & 0.47 & 0.66 & 0.17 & 0.00 & 0.82 & 0.00 & 0.19 & 0.53 \\
\hline 12. Cathedral Cove Marine Reserve & New Zealand & 1 & 1 & 1 & 0 & 0 & 0.64 & 0.83 & 0.31 & 0.00 & 0.91 & 0.00 & 0.26 & 0.60 \\
\hline 19. Florida Keys National Marine Sanctuary a & USA & 1 & 1 & 1 & 0 & 0 & 0.91 & 0.89 & 0.82 & 1.00 & 0.42 & 0.00 & 0.85 & 1.00 \\
\hline 21. Fly Point-Halifax Park & Australia & 1 & 1 & 1 & 0 & 0 & 0.63 & 0.77 & 0.41 & 0.64 & 0.49 & 0.68 & 0.72 & 0.80 \\
\hline 26. Governor Island Marine Nature Reserve & Australia & 1 & 1 & 1 & 0 & 0 & 0.00 & 0.25 & 0.00 & 0.00 & 0.00 & 0.00 & 0.00 & 0.42 \\
\hline 29. Hanauma Bay Marine Life Conservation District & USA & 1 & 1 & 1 & 0 & 0 & 0.52 & 0.46 & 0.43 & 0.00 & 0.36 & 0.00 & 0.76 & 0.77 \\
\hline 35. La Restinga-Mar de las Calmas MPA & Spain & 1 & 1 & 1 & 0 & 0 & 0.57 & 0.71 & 0.59 & 0.87 & 0.47 & 0.00 & 0.42 & 0.99 \\
\hline 36. La Reserve Naturelle Marine de Cerb re Banyuls & France & 1 & 1 & 1 & 0 & 0 & 0.38 & 0.49 & 0.58 & 0.50 & 0.00 & 0.00 & 0.39 & 0.44 \\
\hline 38. Lord Howe Island Marine Park a & Australia & 1 & 1 & 1 & 0 & 0 & 0.80 & 0.96 & 0.93 & 0.55 & 0.69 & 0.87 & 0.69 & 0.65 \\
\hline 41. Maria Island Marine Reserve & Australia & 1 & 1 & 1 & 0 & 0 & 0.29 & 0.51 & 0.00 & 0.00 & 0.29 & 0.40 & 0.25 & 0.58 \\
\hline 42. Marmion Marine Park a & Australia & 1 & 1 & 1 & 0 & 0 & 0.32 & 0.38 & 0.63 & 0.00 & 0.00 & 0.00 & 0.53 & 0.70 \\
\hline 45. Mushi Mas Mingili Thila & Maldives & 1 & 1 & 1 & 0 & 0 & 0.84 & 0.88 & 0.41 & 0.00 & 0.93 & 0.00 & 1.00 & 0.98 \\
\hline 47. Ningaloo Marine Park a & Australia & 1 & 1 & 1 & 0 & 0 & 0.60 & 0.52 & 0.84 & 0.65 & 0.00 & 0.00 & 0.85 & 0.38 \\
\hline 48. Ningaloo Marine Park b & Australia & 1 & 1 & 1 & 0 & 0 & 0.64 & 0.68 & 0.78 & 0.82 & 0.73 & 0.00 & 0.91 & 0.82 \\
\hline 54. Port Noarlunga Reef & Australia & 1 & 1 & 1 & 0 & 0 & 0.47 & 0.69 & 0.52 & 0.00 & 0.00 & 0.00 & 0.57 & 1.00 \\
\hline 59. Rose Atoll National Wildlife Refuge & American Samoa & 1 & 1 & 1 & 0 & 0 & 0.62 & 0.46 & 0.39 & 0.56 & 0.26 & 0.00 & 0.83 & 0.51 \\
\hline 66. Sund Rock Marine Preserve & USA & 1 & 1 & 1 & 0 & 0 & 0.18 & 0.29 & 0.00 & 0.00 & 0.00 & 0.00 & 0.24 & 0.36 \\
\hline 73. Tuhua/Mayor Island marine reserve & New Zealand & 1 & 1 & 1 & 0 & 0 & 0.66 & 0.79 & 0.89 & 0.00 & 0.85 & 0.71 & 0.39 & 0.88 \\
\hline 74. Tulamben & Indonesia & 1 & 1 & 1 & 0 & 0 & 0.65 & 0.70 & 0.97 & 0.50 & 0.49 & 0.00 & 1.00 & 0.89 \\
\hline 27. Great Barrier Reef MP a & Australia & 1 & 1 & 0 & 1 & 0 & 0.67 & 0.67 & 0.99 & 0.78 & 0.61 & 0.65 & 0.93 & 0.63 \\
\hline
\end{tabular}




\begin{tabular}{|c|c|c|c|c|c|c|c|c|c|c|c|c|c|c|}
\hline 33. Kent Group Marine Park a & Australia & 1 & 1 & 0 & 1 & 0 & 0.59 & 0.51 & 0.53 & 0.00 & 0.00 & 0.50 & 0.37 & 0.66 \\
\hline 4. Beware Reef Marine Sanctuary & Australia & 1 & 1 & 0 & 0 & 1 & 0.78 & 0.74 & 0.69 & 0.00 & 0.38 & 0.71 & 0.47 & 0.92 \\
\hline 70. Te Paepae o Aotea Marine Reserve & New Zealand & 1 & 1 & 0 & 0 & 1 & 1.00 & 1.00 & 1.00 & 0.00 & 0.30 & 0.00 & 0.33 & 0.81 \\
\hline 3. Batemans Marine Park a & Australia & 1 & 1 & 0 & 0 & 0 & 0.74 & 0.73 & 0.96 & 0.45 & 1.00 & 0.72 & 0.49 & 0.86 \\
\hline 5. Bushrangers Bay Aquatic Reserve & Australia & 1 & 1 & 0 & 0 & 0 & 0.44 & 0.55 & 0.84 & 0.00 & 0.00 & 0.00 & 0.59 & 0.62 \\
\hline 6. Cabbage Tree Bay Aquatic Reserve & Australia & 1 & 1 & 0 & 0 & 0 & 0.73 & 0.73 & 0.60 & 0.19 & 0.90 & 0.73 & 0.74 & 0.77 \\
\hline 9. Cape Byron Marine Park & Australia & 1 & 1 & 0 & 0 & 0 & 0.88 & 0.98 & 0.84 & 0.60 & 0.64 & 0.86 & 0.86 & 1.00 \\
\hline 10. Cape Howe Marine National Park & Australia & 1 & 1 & 0 & 0 & 0 & 0.78 & 0.68 & 0.58 & 0.00 & 1.00 & 0.78 & 0.50 & 0.93 \\
\hline 13. Channel Islands National Marine Sanctuary a & USA & 1 & 1 & 0 & 0 & 0 & 0.33 & 0.58 & 0.00 & 0.00 & 0.00 & 0.00 & 0.30 & 0.65 \\
\hline 14. Channel Islands National Marine Sanctuary b & USA & 1 & 1 & 0 & 0 & 0 & 0.58 & 0.67 & 0.98 & 0.00 & 0.00 & 0.11 & 0.43 & 0.81 \\
\hline 23. Galapagos Marine Reserve b & Ecuador & 1 & 1 & 0 & 0 & 0 & 1.00 & 1.00 & 0.64 & 0.77 & 0.68 & 1.00 & 0.74 & 1.00 \\
\hline 28. Great Barrier Reef MP b & Australia & 1 & 1 & 0 & 0 & 0 & 0.63 & 0.70 & 0.87 & 0.82 & 0.76 & 0.00 & 1.00 & 0.88 \\
\hline 31. Jervis Bay a & Australia & 1 & 1 & 0 & 0 & 0 & 0.81 & 0.71 & 0.72 & 0.09 & 1.00 & 0.81 & 0.66 & 0.79 \\
\hline 32. Jurien Bay a & Australia & 1 & 1 & 0 & 0 & 0 & 0.39 & 0.54 & 0.79 & 0.51 & 0.00 & 0.00 & 0.47 & 0.60 \\
\hline 50. Point Cooke Marine Sanctuary & Australia & 1 & 1 & 0 & 0 & 0 & 0.00 & 0.00 & 0.00 & 0.00 & 0.00 & 0.00 & 0.00 & 0.00 \\
\hline 51. Point Lobos State Marine Reserve & USA & 1 & 1 & 0 & 0 & 0 & 0.16 & 0.47 & 0.00 & 0.00 & 0.00 & 0.00 & 0.25 & 0.70 \\
\hline 53. Port Davey National Park a & Australia & 1 & 1 & 0 & 0 & 0 & 0.00 & 0.07 & 0.00 & 0.00 & 0.00 & 0.42 & 0.00 & 0.17 \\
\hline 55. Port Phillip Heads Marine National Park & Australia & 1 & 1 & 0 & 0 & 0 & 0.44 & 0.66 & 0.60 & 0.00 & 0.00 & 0.72 & 0.30 & 0.68 \\
\hline 56. Port Stephens Great Lake Marine Park a & Australia & 1 & 1 & 0 & 0 & 0 & 0.71 & 0.57 & 0.69 & 0.25 & 1.00 & 0.68 & 0.67 & 0.70 \\
\hline 58. Rickett's Point Marine Sanctuary & Australia & 1 & 1 & 0 & 0 & 0 & 0.00 & 0.12 & 0.00 & 0.00 & 0.00 & 0.00 & 0.00 & 0.12 \\
\hline 60. Rottnest Island a & Australia & 1 & 1 & 0 & 0 & 0 & 0.65 & 0.80 & 0.65 & 0.39 & 0.29 & 0.42 & 0.56 & 0.67 \\
\hline 65. Solitary Islands Marine Park a & Australia & 1 & 1 & 0 & 0 & 0 & 0.88 & 1.00 & 0.94 & 0.74 & 0.88 & 1.00 & 0.69 & 0.70 \\
\hline 71. Tinderbox Marine Reserve & Australia & 1 & 1 & 0 & 0 & 0 & 0.21 & 0.39 & 0.00 & 0.00 & 0.00 & 0.00 & 0.23 & 0.47 \\
\hline 17. Ponta da Baleia-Abrolhos a & Brazil & 1 & 0 & 1 & 1 & 0 & 0.62 & 0.61 & 0.81 & 0.63 & 0.00 & 0.00 & 0.61 & 0.67 \\
\hline 25. Golfo de Chiriqui Marine National Park & Panama & 1 & 0 & 1 & 1 & 0 & 0.33 & 0.13 & 0.72 & 0.85 & 0.44 & 0.00 & 0.57 & 0.17 \\
\hline 43. Mnazi Bay-Ruvuma Estuary Marine Park & Tanzania & 1 & 0 & 1 & 1 & 0 & 0.59 & 0.34 & 0.78 & 0.67 & 0.00 & 0.00 & 1.00 & 0.70 \\
\hline 2. Baie Ternay & Seychelles & 1 & 0 & 1 & 0 & 0 & 0.71 & 0.65 & 0.56 & 0.53 & 0.00 & 0.00 & 0.98 & 0.80 \\
\hline 30. Isla de Taboga e Isla de Uraba Wildlife Refuge & Panama & 1 & 0 & 1 & 0 & 0 & 0.49 & 0.63 & 0.68 & 0.86 & 0.00 & 0.00 & 0.59 & 0.73 \\
\hline 39. Machalilla & Ecuador & 1 & 0 & 1 & 0 & 0 & 0.45 & 0.52 & 0.79 & 0.84 & 0.00 & 0.00 & 0.64 & 0.67 \\
\hline 49. Pangaimotu Reef MPA & Tonga & 1 & 0 & 1 & 0 & 0 & 0.38 & 0.40 & 0.77 & 0.94 & 0.00 & 0.00 & 0.90 & 0.12 \\
\hline 62. Sesoko Scientific Research Area & Japan & 1 & 0 & 1 & 0 & 0 & 0.57 & 0.00 & 0.79 & 0.32 & 0.00 & 0.00 & 0.97 & 0.12 \\
\hline 64. Shiraiwazaki Marine Park & Japan & 1 & 0 & 1 & 0 & 0 & 0.12 & 0.04 & 0.00 & 0.61 & 0.00 & 0.00 & 0.62 & 0.12 \\
\hline 67. Table Mountain National Park a & South Africa & 1 & 0 & 1 & 0 & 0 & 0.59 & 0.53 & 0.00 & 0.00 & 0.03 & 0.45 & 0.23 & 0.52 \\
\hline 68. Tawharanui Marine Reserve & New Zealand & 1 & 0 & 1 & 0 & 0 & 0.17 & 0.46 & 0.00 & 0.00 & 0.43 & 0.00 & 0.06 & 0.36 \\
\hline 75. Ushibuka Marine Park & Japan & 1 & 0 & 1 & 0 & 0 & 0.40 & 0.24 & 0.57 & 0.75 & 0.00 & 0.00 & 0.66 & 0.29 \\
\hline 16. Coiba National Park a & Panama & 1 & 0 & 0 & 1 & 1 & 0.76 & 0.85 & 0.80 & 0.91 & 0.85 & 0.57 & 0.69 & 0.71 \\
\hline 44. Motu Motiro Hiva & Chile & 1 & 0 & 0 & 1 & 1 & 0.65 & 0.62 & 0.59 & 0.00 & 0.36 & 0.85 & 0.50 & 0.53 \\
\hline 7. Caletas & Costa Rica & 1 & 0 & 0 & 1 & 0 & 0.13 & 0.00 & 0.45 & 0.66 & 0.00 & 0.00 & 0.42 & 0.00 \\
\hline 8. Camaronal & Costa Rica & 1 & 0 & 0 & 1 & 0 & 0.06 & 0.12 & 0.56 & 0.62 & 0.00 & 0.00 & 0.39 & 0.00 \\
\hline 18. Fiordo Comau Protected Area & Chile & 1 & 0 & 0 & 0 & 0 & 0.33 & 0.52 & 0.00 & 0.00 & 0.00 & 0.00 & 0.00 & 0.32 \\
\hline 22. Galapagos Marine Reserve a & Ecuador & 1 & 0 & 0 & 0 & 0 & 1.00 & 1.00 & 0.98 & 1.00 & 0.77 & 1.00 & 0.74 & 1.00 \\
\hline 24. Galapagos Marine Reserve c & Ecuador & 1 & 0 & 0 & 0 & 0 & 1.00 & 0.98 & 0.89 & 1.00 & 0.00 & 0.48 & 0.55 & 1.00 \\
\hline 46. Ninepin Point Marine Reserve & Australia & 1 & 0 & 0 & 0 & 0 & 0.36 & 0.37 & 0.00 & 0.00 & 0.00 & 0.00 & 0.15 & 0.28 \\
\hline 57. Regno di Nettuno a & Italy & 1 & 0 & 0 & 0 & 0 & 0.24 & 0.00 & 0.70 & 0.00 & 0.00 & 0.00 & 0.38 & 0.01 \\
\hline 61. Seaflower Area Marina Protegida a & Colombia & 1 & 0 & 0 & 0 & 0 & 0.59 & 0.57 & 0.59 & 0.70 & 0.44 & 0.00 & 0.77 & 0.63 \\
\hline
\end{tabular}




\begin{tabular}{|c|c|c|c|c|c|c|c|c|c|c|c|c|c|c|}
\hline 69. Te Matuku Marine Reserve & New Zealand & 1 & 0 & 0 & 0 & 0 & 0.00 & 0.00 & 0.00 & 0.00 & 0.00 & 0.00 & 0.00 & 0.00 \\
\hline 101. Lord Howe Commonwealth MPA b & Australia & 0 & 1 & 1 & 1 & 1 & 0.75 & 0.85 & 0.82 & 1.00 & 0.69 & 0.88 & 0.75 & 0.88 \\
\hline 80. Channel Islands National Marine Sanctuary c & USA & 0 & 1 & 1 & 1 & 0 & 0.29 & 0.44 & 0.35 & 0.00 & 0.00 & 0.00 & 0.44 & 0.69 \\
\hline 81. Channel Islands National Marine Sanctuary d & USA & 0 & 1 & 1 & 1 & 0 & 0.56 & 0.42 & 1.00 & 0.00 & 0.00 & 0.00 & 0.41 & 0.57 \\
\hline 86. Florida Keys National Marine Sanctuary c & USA & 0 & 1 & 1 & 1 & 0 & 0.61 & 0.55 & 0.73 & 0.62 & 0.40 & 0.00 & 0.76 & 0.59 \\
\hline 104. Ningaloo Marine Park c & Australia & 0 & 1 & 1 & 1 & 0 & 0.74 & 0.55 & 0.80 & 0.77 & 0.00 & 0.70 & 0.94 & 0.70 \\
\hline 105. Ningaloo Marine Park d & Australia & 0 & 1 & 1 & 1 & 0 & 0.69 & 0.76 & 0.82 & 0.68 & 0.03 & 0.77 & 0.88 & 0.63 \\
\hline 78. Bonaire & Netherlands Antilles & 0 & 1 & 1 & 0 & 1 & 0.56 & 0.56 & 0.91 & 0.48 & 0.33 & 0.00 & 0.84 & 0.90 \\
\hline 87. Fly Point-Halifax Park & Australia & 0 & 1 & 1 & 0 & 0 & 0.39 & 0.46 & 0.29 & 0.33 & 0.00 & 0.54 & 0.72 & 0.55 \\
\hline 102. Lord Howe Island Marine Park b & Australia & 0 & 1 & 1 & 0 & 0 & 0.66 & 0.79 & 0.93 & 0.07 & 0.43 & 0.78 & 0.62 & 0.59 \\
\hline 103. Marmion Marine Park b & Australia & 0 & 1 & 1 & 0 & 0 & 0.74 & 0.92 & 0.70 & 0.36 & 0.17 & 0.00 & 0.48 & 0.64 \\
\hline 106. North Sydney Harbour Aquatic Reserve & Australia & 0 & 1 & 1 & 0 & 0 & 0.64 & 0.69 & 0.81 & 0.00 & 0.85 & 0.29 & 0.66 & 0.66 \\
\hline 114. Rottnest Island c & Australia & 0 & 1 & 1 & 0 & 0 & 0.56 & 0.68 & 0.73 & 0.40 & 0.43 & 0.70 & 0.55 & 0.68 \\
\hline 116. Shoalwater Islands Marine Park & Australia & 0 & 1 & 1 & 0 & 0 & 0.41 & 0.57 & 0.45 & 0.00 & 0.00 & 0.00 & 0.31 & 0.30 \\
\hline 118. St. Abbs and Eyemouth Marine Reserve & Scotland & 0 & 1 & 1 & 0 & 0 & 0.05 & 0.31 & 0.00 & 0.00 & 0.00 & 0.00 & 0.07 & 0.27 \\
\hline 89. Galapagos Marine Reserve e & Ecuador & 0 & 1 & 0 & 1 & 1 & 0.88 & 0.97 & 0.78 & 0.89 & 0.45 & 0.92 & 0.67 & 1.00 \\
\hline 112. Rose Atoll National Monument & American Samoa & 0 & 1 & 0 & 1 & 1 & 0.66 & 0.58 & 0.49 & 0.47 & 0.70 & 0.00 & 0.85 & 0.71 \\
\hline 76. Batemans Marine Park b & Australia & 0 & 1 & 0 & 1 & 0 & 0.74 & 0.77 & 0.90 & 0.18 & 0.99 & 0.78 & 0.49 & 0.85 \\
\hline 91. Great Barrier Reef MP c & Australia & 0 & 1 & 0 & 1 & 0 & 0.64 & 0.63 & 0.92 & 0.58 & 0.26 & 0.64 & 0.91 & 0.47 \\
\hline 94. Jervis Bay b & Australia & 0 & 1 & 0 & 1 & 0 & 0.78 & 0.73 & 0.94 & 0.00 & 1.00 & 0.88 & 0.60 & 0.72 \\
\hline 95. Jurien Bay b & Australia & 0 & 1 & 0 & 1 & 0 & 0.43 & 0.65 & 0.71 & 0.40 & 0.41 & 0.00 & 0.43 & 0.63 \\
\hline 97. Kent Group Marine Park b & Australia & 0 & 1 & 0 & 1 & 0 & 0.53 & 0.49 & 0.58 & 0.00 & 0.00 & 0.44 & 0.40 & 0.67 \\
\hline 100. Levante de Mallorca Cala Ratjada & Spain & 0 & 1 & 0 & 1 & 0 & 0.19 & 0.26 & 0.37 & 0.00 & 0.00 & 0.00 & 0.50 & 0.12 \\
\hline 109. Port Stephens Great Lake Marine Park b & Australia & 0 & 1 & 0 & 1 & 0 & 0.92 & 0.75 & 0.88 & 0.24 & 1.00 & 0.85 & 0.62 & 0.74 \\
\hline 117. Solitary Islands Marine Park b & Australia & 0 & 1 & 0 & 1 & 0 & 0.70 & 0.74 & 0.87 & 0.19 & 0.56 & 0.76 & 0.55 & 0.49 \\
\hline 93. Illa del Toro & Spain & 0 & 1 & 0 & 0 & 1 & 0.54 & 0.54 & 0.95 & 0.74 & 0.00 & 0.00 & 0.48 & 0.73 \\
\hline 79. Bronte-Coogee Aquatic Reserve & Australia & 0 & 1 & 0 & 0 & 0 & 0.55 & 0.55 & 0.67 & 0.00 & 0.62 & 0.00 & 0.63 & 0.64 \\
\hline 92. Great Barrier Reef MP d & Australia & 0 & 1 & 0 & 0 & 0 & 0.58 & 0.50 & 0.81 & 0.71 & 0.00 & 0.00 & 1.00 & 0.70 \\
\hline 108. Port Davey National Park b & Australia & 0 & 1 & 0 & 0 & 0 & 0.01 & 0.22 & 0.00 & 0.00 & 0.04 & 0.37 & 0.00 & 0.32 \\
\hline 110. Pupukea Marine Life Conservation District & USA & 0 & 1 & 0 & 0 & 0 & 0.30 & 0.21 & 0.30 & 0.00 & 0.00 & 0.00 & 0.63 & 0.36 \\
\hline 113. Rottnest Island b & Australia & 0 & 1 & 0 & 0 & 0 & 0.32 & 0.39 & 0.71 & 0.62 & 0.00 & 0.00 & 0.58 & 0.62 \\
\hline 82. Coiba National Park b & Panama & 0 & 0 & 1 & 1 & 1 & 0.85 & 1.00 & 0.71 & 0.94 & 1.00 & 0.80 & 0.65 & 0.73 \\
\hline 84. Coringa-Herald Nature Reserve & Australia & 0 & 0 & 1 & 1 & 1 & 0.61 & 0.77 & 0.66 & 0.63 & 0.48 & 0.90 & 0.98 & 0.66 \\
\hline 85. Ponta da Baleia-Abrolhos b & Brazil & 0 & 0 & 1 & 1 & 0 & 0.56 & 0.59 & 0.66 & 0.00 & 0.17 & 0.00 & 0.61 & 0.63 \\
\hline 119. Strangford Lough Marine Nature Reserve & $\mathrm{N}$ Ireland & 0 & 0 & 1 & 1 & 0 & 0.00 & 0.00 & 0.00 & 0.00 & 0.00 & 0.00 & 0.00 & 0.00 \\
\hline 120. Table Mountain National Park b & South Africa & 0 & 0 & 1 & 1 & 0 & 0.41 & 0.07 & 0.00 & 0.00 & 0.52 & 0.00 & 0.10 & 0.21 \\
\hline 77. Beacon Island Reef Observation Area & Australia & 0 & 0 & 1 & 0 & 1 & 0.69 & 0.88 & 0.67 & 0.82 & 0.16 & 0.00 & 0.67 & 0.94 \\
\hline 83. Coral Patches Reef Observation Area & Australia & 0 & 0 & 1 & 0 & 1 & 0.45 & 0.70 & 0.66 & 0.56 & 0.00 & 0.00 & 0.47 & 0.49 \\
\hline 99. Leo Island Reef Observation Area & Australia & 0 & 0 & 1 & 0 & 1 & 0.65 & 0.72 & 0.72 & 0.59 & 0.00 & 0.00 & 0.60 & 0.77 \\
\hline 96. Kawasan Wisata & Indonesia & 0 & 0 & 1 & 0 & 0 & 0.70 & 0.46 & 0.83 & 0.58 & 0.17 & 0.00 & 1.00 & 0.49 \\
\hline 107. Panglima Laut & Indonesia & 0 & 0 & 1 & 0 & 0 & 0.62 & 0.30 & 0.79 & 0.56 & 0.00 & 0.00 & 1.00 & 0.21 \\
\hline 88. Galapagos Marine Reserve d & Ecuador & 0 & 0 & 0 & 1 & 1 & 1.00 & 1.00 & 0.89 & 0.95 & 0.49 & 0.71 & 0.64 & 1.00 \\
\hline 90. Galapagos Marine Reserve f & Ecuador & 0 & 0 & 0 & 1 & 1 & 0.94 & 1.00 & 0.88 & 1.00 & 0.00 & 0.43 & 0.57 & 1.00 \\
\hline 98. Las Perlas Marine Special Management Zone & Panama & 0 & 0 & 0 & 1 & 1 & 0.84 & 0.80 & 0.93 & 0.97 & 0.73 & 0.49 & 0.72 & 0.81 \\
\hline 111. Regno di Nettuno b & Italy & 0 & 0 & 0 & 1 & 0 & 0.15 & 0.00 & 0.67 & 0.00 & 0.00 & 0.00 & 0.41 & 0.01 \\
\hline
\end{tabular}




\begin{tabular}{|c|c|c|c|c|c|c|c|c|c|c|c|c|c|c|}
\hline 121. Wadi El Gemal - Hamata Reserve & Egypt & 0 & 0 & 0 & 1 & 0 & 0.54 & 0.56 & 0.68 & 0.56 & 0.25 & 0.00 & 1.00 & 0.85 \\
\hline 115. Seaflower Area Marina Protegida b & Colombia & 0 & 0 & 0 & 0 & 1 & 0.99 & 0.71 & 0.30 & 0.00 & 0.28 & 0.00 & 0.84 & 0.81 \\
\hline
\end{tabular}


178

179

180

181

182

183

184

\section{Truth tables}

Truth tables show the connection between all possible configurations of causal conditions that lead to an outcome of interest. The columns represent sets of causal conditions and an outcome, while the rows represent all logically possible intersections among the relevant sets. There is an exponential increase in configuration space as the number of conditions increases, with $2^{k}$ ideal types for $k$ conditions. Assignment of an MPA to a configuration was based on the MPA's membership in each condition's set and the number of empirical instances of each output of interest was recorded for each configuration. The default inclusion level was set at 0.70 (e.g., a configuration with inclusion $=0.72$ would be deemed to 'usually' belong to the set High biomass) for testing sufficiency and 0.90 for testing necessity (see Rihoux and Ragin, 2009). In truth tables, outcomes with inclusion levels in excess of the cut-off were coded as successful (inclusion=1); configurations not meeting the cut-off were coded as unsuccessful (inclusion=0).

\section{Necessary and sufficient conditions}

A truth table forms a Boolean function that can be expressed as a union of fundamental set intersections, each of which corresponds to a successful outcome (Thiem and Duşa 2013). If a condition is necessary for an outcome, the condition is a superset of the outcome (i.e., the outcome occurs only in the presence of the condition). If a condition is sufficient for an outcome, the condition is a subset of the outcome (i.e., the outcome always occurs only in the presence of the condition but also in its absence).

To give a practical example, suppose that high levels of fish biomass were observed in five MPAs, two of which allowed fishing and three of which prohibited fishing: prohibition of fishing would not be a necessary condition for the positive ecological outcome. However, if in 
201 the three cases where fishing was prohibited there were three positive outcomes and no negative

202 outcomes, a prohibition on fishing could be sufficient for achieving the positive ecological 203 outcome.

204 Boolean logic is used to simplify those set relations from the truth table to as few 205 conditions as are defensible from a theoretical or empirical perspective. The level of Boolean 206 minimization depends on assumptions made regarding the feasibility of the 'logical remainders', 207 those configurations for which there are no empirical instances, and the minimum number of empirical instances needed for a configuration to be retained in a model (setting a cut-off level can help dampen noisiness arising from outlying cases). I used a default frequency cut-off of two empirical instances to assess necessary and sufficient conditions. If one assumes that, if

211 observed, none of the logical remainders would result in a positive outcome, the result is the 212 'complex solution'. On the other hand, if one assumes that all logical remainders would result in a positive outcome, a 'parsimonious solution' with the simplest possible sufficiency conditions results. These two solutions bound the complexity of the Boolean sufficiency conditions. In QCA models, solution coverage assesses the extent to which a particular combination of causal conditions accounts for empirical instances of an outcome (Schneider and Wagemann 2012). For example, overall coverage of 0.75 by two sufficient conditions would mean that of all empirical observations of the outcome of interest, $75 \%$ could be explained by one or the other (or both) of the conditions. Consistency, on the other hand, refers to the degree to which cases with a shared combination of causal conditions results in an outcome of interest (Schneider and Wagemann 2012). For example, if a sufficient condition exhibited 0.80 consistency, $80 \%$ of all the occurrences of that particular combination of conditions would lead to the outcome of interest. 
Models

Sixteen models were estimated in total, one each based on the presence or negation of

227

228

229

230

231

232

233

234

235

236

237

238

239

240

each of the eight sets of ecological outcomes (species richness; species richness of large [ $>250$

$\mathrm{mm}$ ] fish; biomass of all fish; biomass of large fish; biomass of damselfish; biomass of jacks; biomass of groupers; biomass of sharks). I used Ragin's fsQCA software (Ragin and Davey 2014) for all analyses.

\section{Results}

With five NEOLI conditions, there were 32 possible combinations of conditions in each model. In total, 27 of the combinations had at least one empirical instance and 23 were observed at least twice and were retained for Boolean simplification (Table 4). Only four MPAs scored highly on all five NEOLI conditions; another five MPAs had various combinations of four of five possible NEOLI conditions (those nine were used by Edgar et al., 2014, as a baseline with which to compare non-fished and fished sites globally). Two configurations with four NEOLI conditions had no empirical instances and so were logical remainders in the QCA analysis. 
Table 4 - Number of empirical observations for each MPA configuration; configurations with no observations (logical remainders) and only one observation (below cut-off for inclusion in QCA model) are noted.

\begin{tabular}{|c|c|c|c|c|c|c|c|}
\hline Configuration & No-take & Enforced & Old & Large & Isolated & Instances & Comments \\
\hline 1 & 1 & 1 & 1 & 1 & 1 & 4 & All 5 NEOLI conditions \\
\hline 2 & 1 & 1 & 1 & 1 & 0 & 2 & 4 NEOLI conditions \\
\hline 3 & 1 & 1 & 1 & 0 & 0 & 20 & 3 NEOLI conditions \\
\hline 4 & 1 & 1 & 1 & 0 & 1 & 2 & 4 NEOLI conditions \\
\hline 5 & 1 & 1 & 0 & 1 & 0 & 2 & 3 NEOLI conditions \\
\hline 6 & 1 & 1 & 0 & 1 & 1 & 0 & Logical remainder \\
\hline 7 & 1 & 1 & 0 & 0 & 0 & 20 & 2 NEOLI conditions \\
\hline 8 & 1 & 1 & 0 & 0 & 1 & 2 & 3 NEOLI conditions \\
\hline 9 & 1 & 0 & 1 & 1 & 0 & 3 & 3 NEOLI conditions \\
\hline 10 & 1 & 0 & 1 & 1 & 1 & 0 & Logical remainder \\
\hline 11 & 1 & 0 & 1 & 0 & 0 & 9 & 2 NEOLI conditions \\
\hline 12 & 1 & 0 & 1 & 0 & 1 & 0 & Logical remainder \\
\hline 13 & 1 & 0 & 0 & 1 & 0 & 2 & 2 NEOLI conditions \\
\hline 14 & 1 & 0 & 0 & 1 & 1 & 2 & 3 NEOLI conditions \\
\hline 15 & 1 & 0 & 0 & 0 & 0 & 7 & 1 NEOLI condition \\
\hline 16 & 1 & 0 & 0 & 0 & 1 & 0 & Logical remainder \\
\hline 17 & 0 & 1 & 1 & 1 & 0 & 5 & 3 NEOLI conditions \\
\hline 18 & 0 & 1 & 1 & 1 & 1 & 1 & Not included in analysis \\
\hline 19 & 0 & 1 & 1 & 0 & 0 & 7 & 2 NEOLI conditions \\
\hline 20 & 0 & 1 & 1 & 0 & 1 & 1 & Not included in analysis \\
\hline 21 & 0 & 1 & 0 & 1 & 0 & 8 & 2 NEOLI conditions \\
\hline 22 & 0 & 1 & 0 & 1 & 1 & 2 & 3 NEOLI conditions \\
\hline 23 & 0 & 1 & 0 & 0 & 0 & 5 & 1 NEOLI condition \\
\hline 24 & 0 & 1 & 0 & 0 & 1 & 1 & Not included in analysis \\
\hline 25 & 0 & 0 & 1 & 1 & 0 & 3 & 2 NEOLI conditions \\
\hline 26 & 0 & 0 & 1 & 1 & 1 & 2 & 3 NEOLI conditions \\
\hline 27 & 0 & 0 & 1 & 0 & 1 & 3 & 2 NEOLI conditions \\
\hline 28 & 0 & 0 & 1 & 0 & 0 & 2 & 1 NEOLI condition \\
\hline 29 & 0 & 0 & 0 & 1 & 1 & 3 & 2 NEOLI conditions \\
\hline 30 & 0 & 0 & 0 & 1 & 0 & 2 & 1 NEOLI condition \\
\hline 31 & 0 & 0 & 0 & 0 & 1 & 1 & Not included in analysis \\
\hline 32 & 0 & 0 & 0 & 0 & 0 & 0 & Logical remainder \\
\hline
\end{tabular}

Necessary Conditions

251 influencing the ecological performance of MPAs. 
252 Table 5 - Tests of necessity for positive and negative ecological outcomes (must be $>=0.90$ to be 253 considered a necessary condition)

\begin{tabular}{|c|c|c|}
\hline & Inclusion & Coverage \\
\hline \multicolumn{3}{|c|}{ High biomass } \\
\hline No-take & 0.61 & 0.55 \\
\hline Enforced & 0.70 & 0.57 \\
\hline Old & 0.53 & 0.56 \\
\hline Large & 0.38 & 0.62 \\
\hline Isolated & 0.28 & 0.79 \\
\hline \multicolumn{3}{|c|}{ NOT[High biomass] } \\
\hline No-take & 0.63 & 0.45 \\
\hline Enforced & 0.65 & 0.43 \\
\hline old & 0.53 & 0.44 \\
\hline Large & 0.29 & 0.38 \\
\hline Isolated & 0.10 & 0.21 \\
\hline \multicolumn{3}{|c|}{ High large fish biomass } \\
\hline No-take & 0.62 & 0.58 \\
\hline Enforced & 0.73 & 0.63 \\
\hline Old & 0.54 & 0.59 \\
\hline Large & 0.35 & 0.61 \\
\hline Isolated & 0.28 & 0.83 \\
\hline \multicolumn{3}{|c|}{ NOT[High large fish biomass] } \\
\hline No-take & 0.62 & 0.42 \\
\hline Enforced & 0.60 & 0.37 \\
\hline old & 0.52 & 0.41 \\
\hline Large & 0.32 & 0.39 \\
\hline Isolated & 0.08 & 0.17 \\
\hline \multicolumn{3}{|c|}{ High damselfish biomass } \\
\hline No-take & 0.58 & 0.55 \\
\hline Enforced & 0.69 & 0.61 \\
\hline Old & 0.52 & 0.58 \\
\hline Large & 0.40 & 0.69 \\
\hline Isolated & 0.26 & 0.77 \\
\hline \multicolumn{3}{|c|}{ NOT[High damselfish biomass] } \\
\hline No-take & 0.68 & 0.45 \\
\hline Enforced & 0.66 & 0.39 \\
\hline old & 0.55 & 0.42 \\
\hline Large & 0.26 & 0.31 \\
\hline Isolated & 0.11 & 0.23 \\
\hline \multicolumn{3}{|c|}{ High grouper biomass } \\
\hline No-take & 0.62 & 0.39 \\
\hline Enforced & 0.57 & 0.33 \\
\hline old & 0.60 & 0.44 \\
\hline Large & 0.45 & 0.52 \\
\hline Isolated & 0.33 & 0.64 \\
\hline \multicolumn{3}{|c|}{ NOT[High grouper biomass] } \\
\hline No-take & 0.62 & 0.61 \\
\hline Enforced & 0.74 & 0.67 \\
\hline Old & 0.49 & 0.56 \\
\hline Large & 0.27 & 0.48 \\
\hline Isolated & 0.12 & 0.36 \\
\hline \multicolumn{3}{|c|}{ High jack biomass } \\
\hline No-take & 0.66 & 0.35 \\
\hline Enforced & 0.81 & 0.39 \\
\hline old & 0.51 & 0.31 \\
\hline
\end{tabular}




\begin{tabular}{|c|c|c|}
\hline Large & 0.41 & 0.40 \\
\hline Isolated & 0.30 & 0.50 \\
\hline \multicolumn{3}{|c|}{ NOT[High jack biomass] } \\
\hline No-take & 0.60 & 0.65 \\
\hline Enforced & 0.61 & 0.61 \\
\hline old & 0.54 & 0.69 \\
\hline Large & 0.30 & 0.60 \\
\hline Isolated & 0.15 & 0.50 \\
\hline \multicolumn{3}{|c|}{ High shark biomass } \\
\hline No-take & 0.60 & 0.27 \\
\hline Enforced & 0.80 & 0.33 \\
\hline old & 0.40 & 0.21 \\
\hline Large & 0.52 & 0.43 \\
\hline Isolated & 0.33 & 0.47 \\
\hline \multicolumn{3}{|c|}{ NOT[High shark biomass] } \\
\hline No-take & 0.63 & 0.73 \\
\hline Enforced & 0.63 & 0.67 \\
\hline old & 0.58 & 0.79 \\
\hline Large & 0.27 & 0.57 \\
\hline Isolated & 0.15 & 0.53 \\
\hline \multicolumn{3}{|c|}{ High species richness } \\
\hline No-take & 0.59 & 0.54 \\
\hline Enforced & 0.67 & 0.56 \\
\hline Old & 0.57 & 0.60 \\
\hline Large & 0.37 & 0.61 \\
\hline Isolated & 0.23 & 0.66 \\
\hline \multicolumn{3}{|c|}{ NOT[High species richness] } \\
\hline No-take & 0.66 & 0.46 \\
\hline Enforced & 0.69 & 0.44 \\
\hline old & 0.48 & 0.40 \\
\hline Large & 0.30 & 0.39 \\
\hline Isolated & 0.16 & 0.34 \\
\hline \multicolumn{3}{|c|}{ High large fish species richness } \\
\hline No-take & 0.63 & 0.62 \\
\hline Enforced & 0.74 & 0.68 \\
\hline Old & 0.53 & 0.62 \\
\hline Large & 0.34 & 0.63 \\
\hline Isolated & 0.27 & 0.83 \\
\hline \multicolumn{3}{|c|}{ NOT[High large fish species richness] } \\
\hline No-take & 0.61 & 0.38 \\
\hline Enforced & 0.57 & 0.32 \\
\hline old & 0.52 & 0.38 \\
\hline Large & 0.33 & 0.37 \\
\hline Isolated & 0.09 & 0.17 \\
\hline
\end{tabular}

255 Sufficient Conditions 
259 two or more empirical instances each, 117 MPAs were represented in 23 NEOLI configurations.

260 Of those, 17 cases in seven configurations exhibited inclusion levels $>0.70$ and were coded as

261 members of (i.e., 'usually in') the set High biomass (Table 6). The High biomass set included the

262 configuration where all five NEOLI conditions were present and one of the two observed

263 configurations with four NEOLI conditions. The other configuration with four NEOLI conditions

264 (No-take, Enforced, Old, Large) fell below the cut-off needed to 'usually' belong to the set High

265 biomass.

266

267 Table 6-High biomass truth table: for MPAs with at least two observations, configuration counts and 268 degree of membership inclusion in the set High biomass

\begin{tabular}{lllllllll}
\hline Configuration & No-take & Enforced & Old & Large & Isolated & Observed & High biomass & Inclusion \\
\hline 1 & 1 & 1 & 1 & 1 & 1 & 4 & 1 & 0.935 \\
2 & 0 & 0 & 0 & 1 & 1 & 3 & 1 & 0.929 \\
3 & 1 & 1 & 0 & 0 & 1 & 2 & 1 & 0.890 \\
4 & 0 & 1 & 0 & 1 & 1 & 2 & 1 & 0.772 \\
5 & 1 & 1 & 1 & 0 & 1 & 2 & 1 & 0.764 \\
6 & 0 & 0 & 1 & 1 & 1 & 2 & 1 & 0.731 \\
7 & 1 & 0 & 0 & 1 & 1 & 2 & 1 & 0.703 \\
\hline 8 & 1 & 1 & 1 & 1 & 0 & 2 & 0 & 0.692 \\
9 & 0 & 0 & 1 & 0 & 0 & 2 & 0 & 0.663 \\
10 & 1 & 1 & 0 & 1 & 0 & 2 & 0 & 0.629 \\
11 & 0 & 1 & 0 & 1 & 0 & 8 & 0 & 0.617 \\
12 & 0 & 0 & 1 & 0 & 1 & 3 & 0 & 0.596 \\
13 & 0 & 1 & 1 & 1 & 0 & 5 & 0 & 0.578 \\
14 & 1 & 1 & 1 & 0 & 0 & 20 & 0 & 0.530 \\
15 & 1 & 1 & 0 & 0 & 0 & 20 & 0 & 0.518 \\
16 & 1 & 0 & 1 & 1 & 0 & 3 & 0 & 0.513 \\
17 & 1 & 0 & 0 & 0 & 0 & 7 & 0 & 0.501 \\
18 & 0 & 1 & 1 & 0 & 0 & 7 & 0 & 0.492 \\
19 & 1 & 0 & 1 & 0 & 0 & 9 & 0 & 0.430 \\
20 & 0 & 1 & 0 & 0 & 0 & 5 & 0 & 0.353 \\
21 & 0 & 0 & 0 & 1 & 0 & 2 & 0 & 0.344 \\
22 & 0 & 0 & 1 & 1 & 0 & 3 & 0 & 0.324 \\
23 & 1 & 0 & 0 & 1 & 0 & 2 & 0 & 0.098 \\
\hline
\end{tabular}

In the model's complex solution (equation 1.C), five different pathways, derived by

271 Boolean manipulation of the combinations of conditions in rows 1-7 of Table 6, were sufficient

272 to result in high levels of fish biomass. Five conditions in each pathway are combined by logical

273 AND operators; upper case denotes presence of condition and lower case denotes absence of a 
274 condition; dash denotes that a condition can be either present or absent; + denotes logical OR).

275 To illustrate, the first condition, $-e o \boldsymbol{L I}$, can be interpreted as follows: to achieve high levels of

276 overall fish biomass via pathway 1.C1, the MPA can be either fished or not (i.e., $N$ has no effect)

277 AND enforcement is absent AND the MPA is not more than 10 years old AND the MPA is

278 larger than $100 \mathrm{~km}^{2}$ AND the MPA is ecologically isolated (note that this corresponds to a total

279 of 5 MPAs in the sample, the configuration represented by rows 2 and 7 in Table 6). In

280 aggregate, the five pathways in the complex solution in combination provided 0.211 coverage

281 and their level of aggregate inclusion was 0.838 . The five pathways themselves each provided

282 between 0.049 and 0.078 raw coverage individually; unique coverage for each pathway ranged

283 from 0.021 to 0.055 and inclusion levels ranged from 0.827 to 0.878 .

284

285

286

287

288

289

290

291

292

293

294

295

296

297

$$
-e o \boldsymbol{L I}+n-o \boldsymbol{L I}+n e-\boldsymbol{L I}+\boldsymbol{N E}-\boldsymbol{l I}+\mathbf{N E O} \boldsymbol{I} \rightarrow \text { High biomass }
$$

1.C

could have either positive or negative effects on overall fish biomass depending on the context in which they occurred. While it may at superficially appear that Isolated is necessary for High biomass outcomes (because Isolated appears in each of the five pathways that combine to lead to High biomass), recall that the definition of a necessary condition is that it is a superset of the outcome: the outcome only appears in the presence of the condition. Table 6 showed, however, that row 12 (neOlI) had three empirical instances where High biomass was not achieved even though the MPAs were isolated; if Isolated were a necessary condition, these MPAs would also have exhibited a High biomass outcome. Neither can one say that Isolated is sufficient, on its own, to lead to positive outcomes. Considering only cases where High biomass was observed the first seven rows of Table 6 - Isolated appears in all configurations but never on its own, only 
298 in combination with other conditions in the seven distinct MPA configurations that lead to High

299 biomass. Eight of nine logical remainders included Isolated, further highlighting the potential

300 nuance of the role of ecological isolation - the complex solution assumes that none of the logical

301 remainders would, if actually observed, result in high biomass (a point we return to in the

302 Discussion).

303 Solution 1.C exhibited configurational complexity in that multiple alternative pathways

304 led to a single outcome of interest. The first three pathways comprising the complex solution

305 highlighted that large, isolated MPAs could compensate, in terms of overall production of fish

306 biomass, for some fishing within MPAs or in the face of weak enforcement, even in young

307 MPAs. Pathways three and four implied that Large and the combination of No-take and

308 Enforced were substitutes in the production of high levels of fish biomass within MPAs.

309 When the five pathways in the complex solution were simplified as much as possible

310 with Boolean logic (i.e., assuming all logical remainders, if actually observed, would result in

311 High biomass), the parsimonious solution (1.P) consisted of two pathways sufficient for

312 achieving high levels of fish biomass within MPAs:

313

314

$\boldsymbol{L I}+\boldsymbol{E I} \rightarrow$ High biomass

1.P

315

316

Based on the ecological performance of the 17 MPAs that surpassed a reasonable

threshold that qualified them as members of the set High biomass, ecological isolation in

combination with either large area or effective enforcement were the simplest configurations that

led to High biomass on a consistent basis. MPAs needed have only two NEOLI conditions and

neither solution involved the presence of either No-take or $\boldsymbol{O}$ ld. Moving from the complex to

321 parsimonious solution increased coverage slightly from 0.211 to 0.238 and reduced inclusion 
322 from 0.838 to 0.804 . The parsimonious pathways did not demonstrate the same level of subtlety

323 as did the more stringent complex model. In the complex solution, a total of 17 specific MPAs

324 were covered by the five sufficient pathways leading to High biomass (Table 7). A total of 20

325 MPAs were covered under the less stringent parsimonious solution.

326

327

328

Table 7 - MPAs with greater than 50\% membership in the sufficient condition High biomass. Italics indicate MPAs not covered in the complex solution but covered under the parsimonious solution

\begin{tabular}{|c|c|c|c|c|c|c|c|}
\hline \multirow[b]{2}{*}{ Case } & \multicolumn{5}{|c|}{ Complex } & \multicolumn{2}{|c|}{ Parsimonious } \\
\hline & $1 . \mathrm{C} 1$ & $1 . \mathrm{C} 2$ & $1 . \mathrm{C} 3$ & $1 . \mathrm{C} 4$ & $1 . \mathrm{C} 5$ & 1.P1 & $1 . \mathrm{P} 2$ \\
\hline 4. Beware Reef Marine Sanctuary & & & & 1 & & & 1 \\
\hline 15. Cocos National Park & & & & & 1 & 1 & 1 \\
\hline 16. Coiba National Park $b$ & 1 & & & & & 1 & \\
\hline 34. Kermadec Marine Reserve & & & & & 1 & 1 & 1 \\
\hline 37. Lord Howe Commonwealth MPA $a$ & & & & & 1 & 1 & 1 \\
\hline 40. Malpelo Flora and Fauna Sanctuary & & & & & 1 & 1 & 1 \\
\hline 44. Motu Motiro Hiva & 1 & & & & & 1 & \\
\hline 52. Poor Knights Island Marine Reserve & & & & 1 & 1 & & 1 \\
\hline 63. Shiprock Aquatic Reserve & & & & 1 & 1 & & 1 \\
\hline 70. Te Paepae o Aotea Marine Reserve & & & & 1 & & & 1 \\
\hline 78. Bonaire & & & & & & & 1 \\
\hline 82. Coiba National Park & & & 1 & & & 1 & \\
\hline 84. Coringa-Herald Nature Reserve & & & 1 & & & 1 & \\
\hline 88. Galapagos Marine Reserve $d$ & 1 & 1 & 1 & & & 1 & \\
\hline 89. Galapagos Marine Reserve $e$ & & 1 & & & & 1 & 1 \\
\hline 90. Galapagos Marine Reserve $f$ & 1 & 1 & 1 & & & 1 & \\
\hline 93. Illa del Toro & & & & & & & 1 \\
\hline 98. Las Perlas Marine Special Management Zone & 1 & 1 & 1 & & & 1 & \\
\hline 101. Lord Howe Commonwealth MPA b & & & & & & 1 & 1 \\
\hline 112. Rose Atoll National Monument & & 1 & & & & 1 & 1 \\
\hline
\end{tabular}

329

There were 14 cases with greater than 0.50 membership in pathway $\boldsymbol{L I}$ [Large AND

331 Isolated], 13 cases with greater than 0.50 membership were covered by pathway $\boldsymbol{E I}$ [Enforced

AND Isolated], and an overlap of 7 cases. Figure 1A shows an area-proportional Venn diagram

(Micallef and Rodgers 2014) with the set High biomass normalized to 100\%. Solution coverage

was $0.238(0.065+0.089+0.084)$ : the two solution pathways covered $23.8 \%$ of the area the set

High biomass and the solution inclusion was 0.804 (i.e., $19.6 \%$ of the area of the two sufficient

MPAs are mapped onto the sets of conditions and outcome. Low coverage left much of the set of 
338 High biomass unexplained and implies other conditions and sufficiency pathways are important

339 in explaining high levels of overall fish biomass at the 121 MPAs.
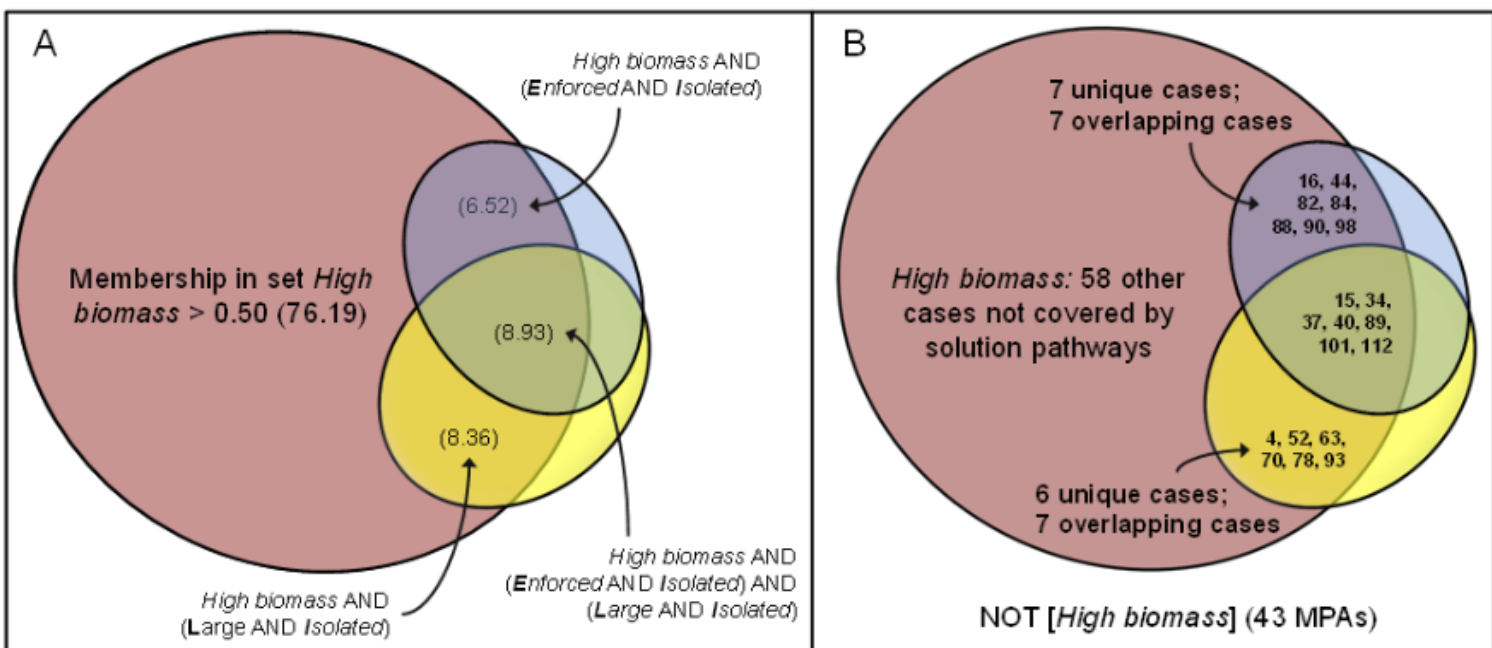

Figure

1 - Parsimonious solution for High Biomass outcomes: (A) in terms of solution coverage by each of two pathways sufficient to achieve High Biomass; and (B) with specific MPAs that are members of pathways

A more stringent consistency cut-off in the model would constrain solution boundaries.

For example, increasing the inclusion cut-off to 0.85 in the first stage of the modeling process

(i.e., imposing a more stringent definition of 'usually in' the set High biomass) would reduce the number of cases used in the Boolean analysis to nine empirical instances (coverage $=0.145)$ arising from three different configurations of MPA conditions (all still involving Isolated).

\section{Model 2: NOT[High biomass]}

In addition to analysis of positive ecological outcomes from MPAs, the QCA analysis in the second model identified sufficient conditions needed to lead to set negation, the set of all MPAs belonging to NOT[High biomass]. Two cases in a single configuration exhibited consistency levels $>0.70$ and were coded as members of the set NOT[High biomass]. The complex solution could not be simplified, coverage was 0.034 , and a single pathway (equation 2.C/2.P) described a sufficient condition leading to the absence of high levels of fish biomass: 

could not be explained by this solution, implying that other pathways not dependent on either the species - see models 8, 10, and 12 below).

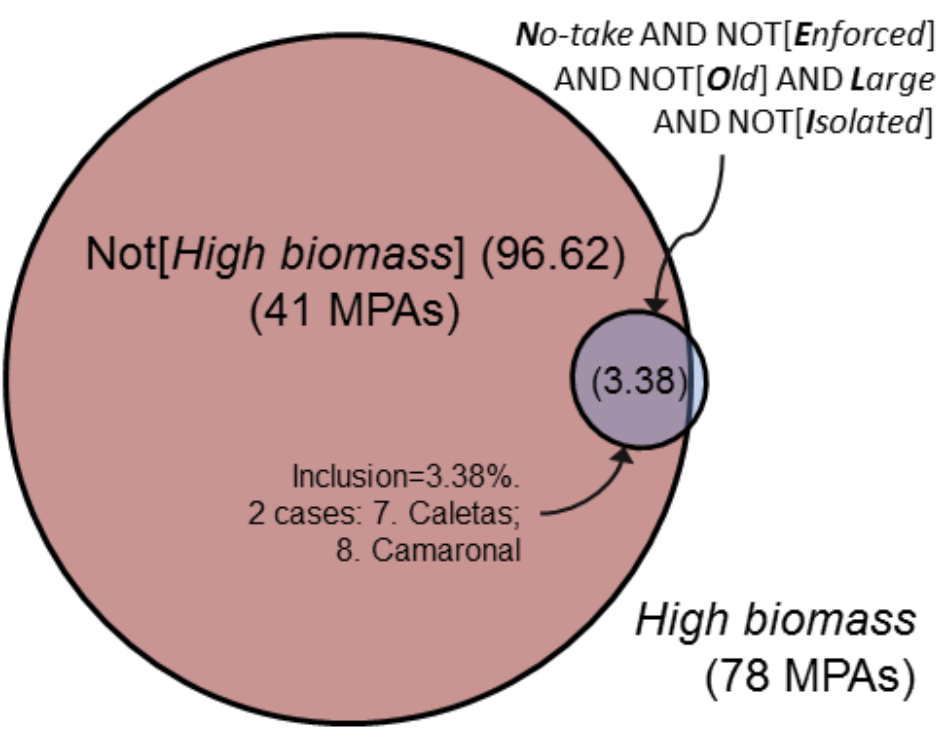

Figure 2 - Venn diagram of solution coverage for model 2, NOT[High biomass]

\section{Model 3: High large fish biomass}

The complex solution (3.C) consisted of five pathways sufficient to lead to High large

fish biomass. Table 8 shows model diagnostics for all parsimonious solutions leading to positive ecological outcomes. The parsimonious solution (3.P) consisted of a single pathway comprised 
374 of a single condition, ecological isolation. Three MPAs that were not part of the complex

375 solution (78. Bonaire; 101. Lord Howe Commonwealth MPA b; 115. Seaflower Area Marina

376 Protegida $b$ ) were part of the parsimonious solution simply by virtue of their ecological isolation.

377

378

$n e \boldsymbol{O} \boldsymbol{I}+-e o \boldsymbol{L I}+n-o \boldsymbol{L I}+\boldsymbol{N E}-\boldsymbol{l I}+\mathbf{N E O}-\boldsymbol{I} \rightarrow$ High large fish biomass

3. $C$

379

$----I \rightarrow$ High large fish biomass

3.P

380

381

382 
Table 8 - Summary of parsimonious QCA solutions for positive outcomes: conditions, performance, and total coverage of MPAs by pathway and models (upper case/bold denotes presence required; lower case denotes absence required [i.e., NOT set member]; dash denotes condition may be present or absent)

\begin{tabular}{|c|c|c|c|c|c|c|c|c|c|c|c|}
\hline \multirow[b]{2}{*}{ Set / pathways to membership in set } & \multicolumn{5}{|c|}{ MPA NEOLI conditions in sufficient solution } & \multirow[b]{2}{*}{ MPAs covered ${ }^{a}$} & \multicolumn{2}{|c|}{ Model performance } & \multicolumn{2}{|c|}{ Pathway performance } & \multirow[b]{2}{*}{$\begin{array}{l}\text { Pathway } \\
\text { inclusion }\end{array}$} \\
\hline & No-take & Enforced & old & Large & Isolated & & $\begin{array}{l}\text { Overall } \\
\text { coverage }\end{array}$ & $\begin{array}{l}\text { Overall } \\
\text { inclusion }\end{array}$ & $\begin{array}{l}\text { Raw } \\
\text { coverage }\end{array}$ & $\begin{array}{l}\text { Unique } \\
\text { coverage }\end{array}$ & \\
\hline Model P.1: High biomass & & & & & & 20 & 0.238 & 0.804 & & & \\
\hline Pathway 1 & - & - & - & $\boldsymbol{L}$ & $I$ & 14 & & & 0.173 & 0.084 & 0.835 \\
\hline Pathway 2 & - & $\boldsymbol{E}$ & - & - & $I$ & 13 & & & 0.154 & 0.065 & 0.803 \\
\hline Model P.3: High large fish biomass & & & & & & 20 & 0.280 & 0.827 & & & \\
\hline Pathway 1 & - & - & - & - & $I$ & 20 & & & 0.280 & 0.280 & 0.827 \\
\hline Model P.5: High damselfish biomass & & & & & & 32 & 0.348 & 0.780 & & & \\
\hline Pathway 1 & $N$ & $\boldsymbol{E}$ & - & - & $I$ & 8 & & & 0.093 & 0.093 & 0.831 \\
\hline Pathway 2 & $n$ & $e$ & - & $l$ & $i$ & 2 & & & 0.022 & 0.022 & 0.806 \\
\hline Pathway 3 & $n$ & $e$ & $o$ & - & $\boldsymbol{I}$ & 4 & & & 0.042 & 0.042 & 0.754 \\
\hline Pathway 4 & - & $\boldsymbol{E}$ & $o$ & $L$ & $i$ & 10 & & & 0.107 & 0.021 & 0.769 \\
\hline Pathway 5 & $n$ & $\boldsymbol{E}$ & - & $L$ & $i$ & 13 & & & 0.137 & 0.052 & 0.760 \\
\hline Pathway 6 & $N$ & $e$ & $\boldsymbol{O}$ & $L$ & - & 3 & & & 0.032 & 0.032 & 0.766 \\
\hline Model P.7: High grouper biomass & & & & & & 13 & 0.240 & 0.870 & & & \\
\hline Pathway 1 & - & - & $\boldsymbol{O}$ & $\boldsymbol{L}$ & $I$ & 7 & & & 0.132 & 0.099 & 0.892 \\
\hline Pathway 2 & $n$ & $e$ & - & $L$ & $I$ & 5 & & & 0.095 & 0.062 & 0.897 \\
\hline Pathway 3 & $N$ & $e$ & $\boldsymbol{O}$ & $\boldsymbol{L}$ & - & 3 & & & 0.046 & 0.046 & 0.716 \\
\hline Model P.9: High jacks biomass & & & & & & 10 & 0.183 & 0.729 & & & \\
\hline Pathway 1 & - & - & $\boldsymbol{O}$ & $L$ & $\boldsymbol{I}$ & 7 & & & 0.134 & 0.037 & 0.759 \\
\hline Pathway 2 & $N$ & - & $\boldsymbol{O}$ & - & $\boldsymbol{I}$ & 6 & & & 0.120 & 0.000 & 0.798 \\
\hline Pathway 3 & - & $\boldsymbol{E}$ & $\boldsymbol{O}$ & - & $\boldsymbol{I}$ & 8 & & & 0.146 & 0.008 & 0.726 \\
\hline Model P.11: High shark biomass & & & & & & 9 & 0.237 & 0.890 & & & \\
\hline Pathway 1 & - & - & $\boldsymbol{O}$ & $L$ & $I$ & 7 & & & 0.195 & 0.195 & 0.941 \\
\hline Pathway 2 & $N$ & $e$ & - & - & $I$ & 2 & & & 0.042 & 0.042 & 0.713 \\
\hline Model P.13: High species richness & & & & & & 11 & 0.128 & 0.794 & & & \\
\hline Pathway 1 & $n$ & $e$ & - & $l$ & $i$ & 2 & & & 0.029 & 0.029 & 1.000 \\
\hline Pathway 2 & $n$ & $e$ & $o$ & - & $i$ & 2 & & & 0.021 & 0.021 & 0.705 \\
\hline Pathway 3 & $N$ & $e$ & $\boldsymbol{O}$ & $L$ & $i$ & 3 & & & 0.032 & 0.032 & 0.726 \\
\hline Pathway 4 & - & $E$ & $o$ & $L$ & $I$ & 2 & & & 0.022 & 0.022 & 0.756 \\
\hline Pathway 5 & - & $e$ & $\boldsymbol{O}$ & $\boldsymbol{L}$ & $\boldsymbol{I}$ & 2 & & & 0.024 & 0.024 & 0.818 \\
\hline Model P.15: High large species & & & & & & 21 & & & & & \\
\hline richness & & & & & & & 0.240 & 0.854 & & & \\
\hline Pathway 1 & - & - & - & $l$ & $I$ & 10 & & & 0.108 & 0.087 & 0.808 \\
\hline Pathway 2 & $n$ & - & $o$ & - & $I$ & 7 & & & 0.081 & 0.060 & 0.867 \\
\hline Pathway 3 & $N$ & $E$ & $O$ & $L$ & - & 6 & & & 0.071 & 0.071 & 0.887 \\
\hline
\end{tabular}


387

388

389

390

391

392

393

394

395

396

397

398

399

400

401

402

403

404

405

406

407

408

\section{Model 4: NOT[High large fish biomass]}

In total, seven MPAs were used to calculate a parsimonious solution (4.P) that included two sufficient pathways to membership in NOT[High large fish biomass] (Table 9 shows parsimonious solutions for all negated models; all complex solutions are available from the author upon request). In model 4, the parsimonious and complex solutions (4.C) coincided as no Boolean simplifications were possible. Note that, contrary to received wisdom about MPA size, Large figured in both sufficient pathways to low biomass outcomes; but recall it was also a condition in two pathways to High large fish biomass, demonstrating that the effect of MPA size was highly context dependent.

$$
-e o L i+n e-L i \rightarrow \text { NOT[High large fish biomass] }
$$

4.P/4.C

\section{Models 5 to 16}

The remaining models for various ecological outcomes are outlined in Tables 8 and 9. Note that in Model 8 a total of 40 cases in seven configurations were coded as members of the negated set NOT[High grouper biomass]. This was the first model to achieve over 0.50 coverage, where four sufficient pathways in the parsimonious solution accounted for over half of all observed MPAs with low levels of grouper biomass. Similarly, 42 cases (coverage $=0.542)$ in Model 10 and 54 cases in Model $12($ coverage $=0.706)$ were coded as members of the negated sets NOT[High jack biomass] and NOT[High shark biomass], respectively. For all three commercially-targeted species, negated solutions had much higher coverage levels compared to more general biomass or species richness outcomes. Lack of ecological isolation was an important factor in virtually all solution pathways (Table 9). 
Table 9 - Summary of parsimonious QCA model solutions for negated models: conditions, performance, and total coverage of MPAs by pathway

\begin{tabular}{|c|c|c|c|c|c|c|c|c|c|c|c|}
\hline \multirow[b]{2}{*}{ Set / pathways to membership in set } & \multicolumn{5}{|c|}{ MPA NEOLI conditions } & \multirow[b]{2}{*}{$\begin{array}{l}\text { MPAs } \\
\text { covered }\end{array}$} & \multicolumn{2}{|c|}{ Model performance } & \multicolumn{2}{|c|}{ Pathway performance } & \multirow[b]{2}{*}{$\begin{array}{l}\text { Pathway } \\
\text { inclusior }\end{array}$} \\
\hline & No-take & Enforced & Old & Large & Isolated & & $\begin{array}{l}\text { Overall } \\
\text { coverage }\end{array}$ & $\begin{array}{l}\text { Overall } \\
\text { inclusion }\end{array}$ & $\begin{array}{l}\text { Raw } \\
\text { coverage }\end{array}$ & $\begin{array}{l}\text { Unique } \\
\text { coverage }\end{array}$ & \\
\hline NEGATIVE OUTCOMES & & & & & & & & & & & \\
\hline Model P.2: NOT[High biomass] & & & & & & 2 & 0.034 & 0.903 & & & \\
\hline Pathway 1 & $N$ & $e$ & $o$ & $\boldsymbol{L}$ & $i$ & 2 & & & 0.034 & 0.034 & 0.903 \\
\hline Model P.4: NOT[High large fish biomass] & & & & & & 7 & 0.113 & 0.807 & & & \\
\hline Pathway 1 & - & $e$ & $o$ & $L$ & $i$ & 4 & & & 0.066 & 0.038 & 0.829 \\
\hline Pathway 2 & $n$ & $e$ & - & $L$ & $i$ & 5 & & & 0.075 & 0.047 & 0.755 \\
\hline Model P.6: NOT[High damselfish biomass] & & & & & & 3 & 0.048 & 0.781 & & & \\
\hline Pathway 1 & $n$ & $e$ & $\boldsymbol{O}$ & $L$ & $i$ & 3 & & & 0.048 & 0.048 & 0.781 \\
\hline Model P.8: NOT[High grouper biomass] & & & & & & 40 & 0.519 & 0.782 & & & \\
\hline Pathway 1 & $n$ & - & $o$ & - & $i$ & 15 & & & 0.156 & 0.087 & 0.768 \\
\hline Pathway 2 & - & $E$ & $o$ & $l$ & - & 20 & & & 0.286 & 0.233 & 0.755 \\
\hline Pathway 3 & $n$ & $E$ & - & $l$ & - & 14 & & & 0.139 & 0.086 & 0.735 \\
\hline Pathway 4 & $n$ & $e$ & - & $L$ & $i$ & 5 & & & 0.060 & 0.041 & 0.887 \\
\hline Model P.10: NOT[High jack biomass] & & & & & & 42 & 0.542 & 0.864 & & & \\
\hline Pathway 1 & - & $e$ & - & - & $i$ & 20 & & & 0.305 & 0.254 & 0.885 \\
\hline Pathway 2 & $n$ & - & - & $l$ & - & 19 & & & 0.203 & 0.118 & 0.827 \\
\hline Pathway 3 & $n$ & - & $\boldsymbol{O}$ & - & $i$ & 17 & & & 0.170 & 0.056 & 0.814 \\
\hline Model P.12: NOT[High shark biomass] & & & & & & 54 & 0.706 & 0.905 & & & \\
\hline Pathway 1 & - & $e$ & - & - & $i$ & 20 & & & 0.299 & 0.132 & 0.931 \\
\hline Pathway 2 & $n$ & - & $o$ & $l$ & - & 7 & & & 0.076 & 0.076 & 0.947 \\
\hline Pathway 3 & - & - & $\boldsymbol{O}$ & $L$ & $i$ & 13 & & & 0.132 & 0.040 & 0.887 \\
\hline Pathway 4 & - & - & $\boldsymbol{O}$ & $l$ & $I$ & 6 & & & 0.069 & 0.069 & 1.000 \\
\hline Pathway 5 & $N$ & - & $\boldsymbol{O}$ & - & $i$ & 20 & & & 0.354 & 0.199 & 0.909 \\
\hline Model P.14: NOT[High species richness] & & & & & & 3 & 0.044 & 0.765 & & & \\
\hline Pathway 1 & $n$ & $e$ & $\boldsymbol{O}$ & $L$ & $i$ & 3 & & & 0.044 & 0.044 & 0.765 \\
\hline $\begin{array}{l}\text { Model P.16: NOT[High large species } \\
\text { richness] }\end{array}$ & & & & & & 5 & 0.090 & 0.831 & & & \\
\hline Pathway 1 & $N$ & $e$ & $o$ & $\boldsymbol{L}$ & $i$ & 2 & 0.090 & 0.051 & 0.043 & 0.043 & 1.000 \\
\hline Pathway 2 & $n$ & $e$ & $\boldsymbol{O}$ & $L$ & $i$ & 3 & & & 0.047 & 0.047 & 0.718 \\
\hline
\end{tabular}




\section{Discussion}

413 This study identified pathways that led from MPA design and management conditions to

414 MPA performance, measured in terms of fish species richness and biomass for all fish, large fish, 415 and specific groups of species (damselfish, groupers, jacks, sharks). The results demonstrated the 416 importance of considering ecological and managerial conditions in the MPA design and 417 implementation process. In addition to the substantive results, this study demonstrated the 418 potential utility of QCA and set theory to assess the determinants of MPA performance and, 419 more generally, how set theoretic approaches to ecological success may complement and extend 420 insights from statistical analyses.

Conditions and configurations influencing ecological success

One of the five NEOLI conditions - ecological isolation - was pivotal for positive

424 425

ecological outcomes relating to species richness of large fish and biomass of all fish, of large fish only, and of three commercially exploited fishes (groupers, jacks and sharks). Isolation was in fact, on its own, sufficient for leading to high biomass of large fish in the parsimonious solution. Isolated was present in 12 of 14 pathways to positive ecological performance in parsimonious solutions (Table 8) and NOT[Isolated] was not present in any. For complex solutions (available from the author upon request), Isolated was present in 20 of 22 pathways to positive ecological performance (NOT[Isolated] was present in only one solution). Conversely, in the negated models examining conditions influencing poor MPA performance, NOT[Isolated] was present in 14 of 17 pathways in parsimonious solutions (Table 9) (Isolated was present in one solution) and 17 of 21 in complex solutions. 
Edgar et al. (2014) found that ecological isolation was important, seeming to "exert a

435

436

437

438

439

stronger influence for community-level biomass and richness metrics than the other four features... [and that] although very important, the effect of isolation was similar in magnitude rather than clearly superior - to other MPA features for biomass of sharks, groupers and jacks" (p. 218). QCA results instead suggest that ecological isolation is clearly the most important factor affecting ecological performance. The importance of isolation aligns well with insights from ecological models of MPAs (e.g., White et al. 2011).

Other areas of discrepancy between the statistical and set-theoretic models included the importance of: no-take regulations in the production of overall fish biomass (not part of QCA pathways to success in the parsimonious solutions and conflicting in direction in the complex solutions); MPA age being related to higher levels of jack biomass; and the effects of No-take and Enforced on species richness in MPAs (QCA results suggested that Old and Isolated also play important contextual roles). On other ecological outcomes, however, the approaches converged. For example, both statistical and set theoretic approaches identified lack of enforcement as being associated with relatively low levels of grouper biomass and identified the role of old MPAs in the production of high levels of shark biomass.

All conditions other than ecological isolation could positively or negatively affect positive ecological outcomes for large species diversity and biomass measures, thus highlighting the importance of context on success. Large MPAs appeared to, on balance, be important for positive outcomes and older MPAs appeared to be more important for commercially landed species compared to large species in general. MPA no-take regulations and enforcement did not have any degree of clear directional influence on ecological outcomes; in particular the $\mathbf{N E O}$ combination (row 14, Table 6), comprising 20 observations, had no positive or few minor 
457 negative impacts on ecological performance. Figure 3 illustrates all possible overlapping set

458 combinations for the five NEOLI conditions and the number of empirical instances for each

459 configuration. MPA performance, measured as the difference in the number of times a NEOLI

460 condition was part of positive and negative parsimonious solutions, suggests that MPA

461 ecological outcomes were broadly mediocre in the absence of ecological isolation.

462 Overall, NEOLI conditions played a relatively limited role in sustaining high levels of 463 ecological performance in MPAs. Solution coverage ranged from 0.128 for the species richness

464 model to 0.348 for the damselfish biomass model, implying that $65 \%$ or more of positive

465 ecological outcomes observed in the field could not be explained in terms of NEOLI conditions

466 alone or in combination. On the other hand, the higher levels of coverage in the negated models

467 of jack (0.542), grouper (0.519) and shark (0.706) biomass lends support for the perspective that

468 MPAs may provide performance asymmetries and be more effective in preventing further

469 declines in large fish biomass relative to rebuilding biomass towards levels seen in near-pristine

470 conditions. Among the negated models, there were large differences in solution coverage

471 between biomass outcomes for the large commercially-exploited species and the more general

472 biomass and species richness models. This hints that there may be potential economic benefits

473 for capture fisheries and tourism (for wildlife viewing) from conservation-oriented MPAs that

474 provide insurance against declines in biomass of relatively mobile large species. 


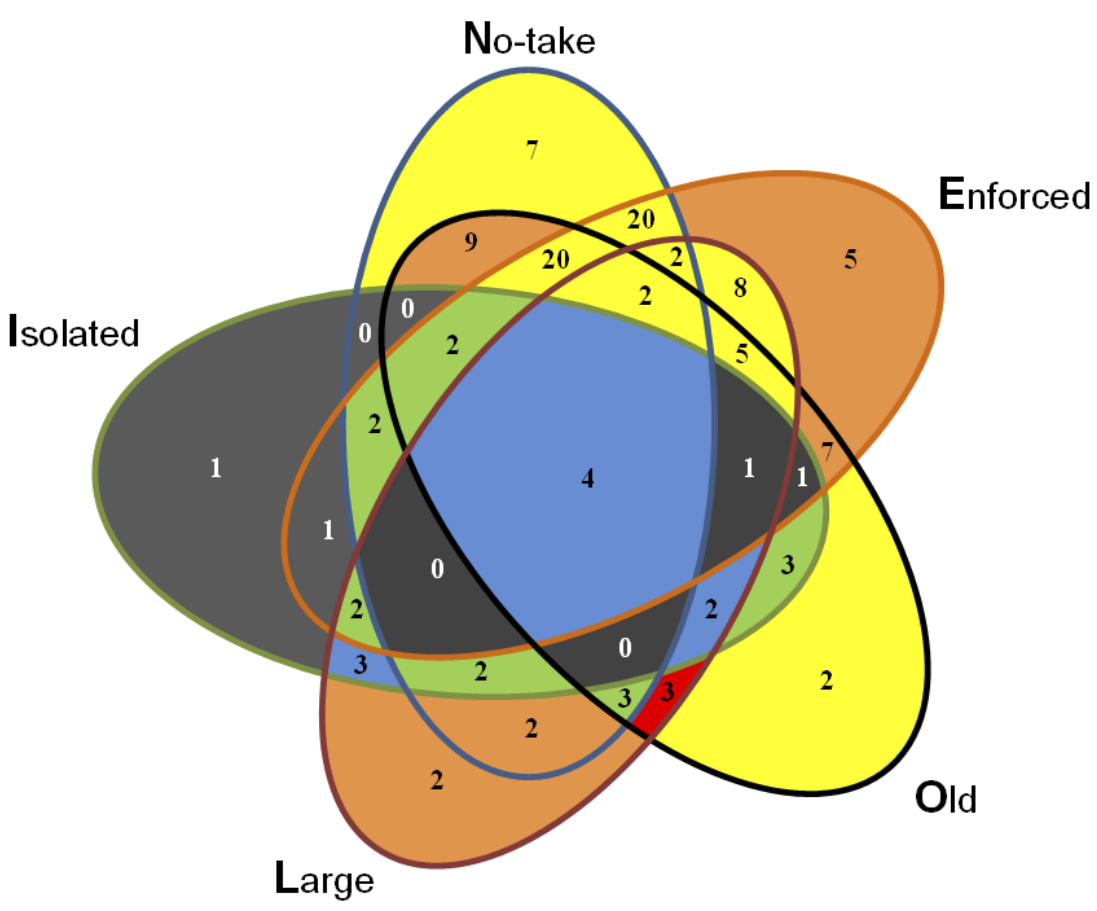

Figure 3 - Count of MPAs exhibiting various combinations of conditions. Gray fill indicates configurations that were absent or observed at only a single site in the Reef Life Survey dataset. The colored configurations indicate the difference in times that particular configurations were present in parsimonious solutions less the times they appeared in negative solutions: blue fill indicates top performing MPA configurations (positive minus negative outcomes $=+5,+6$ or +7 ); green $=+2,+3$ or +4 ; yellow $=-1,0$ or +1 ; orange $=-4,-3$ or -2 ; and red $=-5,-6$ or -7 .

For damselfish biomass, biomass levels for all fish, and for large fish only, and for both species richness metrics, the negated models only covered $3 \%$ to $11 \%$ of all negative outcomes. For the models with low coverage, the implication is that conditions other than the NEOLI conditions account for the vast majority of MPA buffering capacity against adverse ecological outcomes. A wide variety of other conditions have been identified as potentially important for MPA and small-scale fisheries management; some possible candidates include fishing community leadership, residents' perceptions regarding threats to fish stocks, the availability of alternative livelihood opportunities, high levels of community engagement, management accountability, social capital and trust among community members, and outside (e.g., NGO) support for local management (e.g., Gutiérrez et al. 2011; Pollnac et al. 2001; Rudd et al. 2003; 
493 Warner and Pomeroy 2012; Sutton and Rudd 2015). Given the variability even among the eight

494 indicators used in this study, it may also be the case that NEOLI conditions positively affect

495 levels of alternative performance metrics. Many ecological indicators of MPA success are

496 possible (Soykan and Lewison 2015) and futher investigation would be needed to clarify the

497 relationship between NEOLI conditions and a broader suite of ecological outcomes. The

498 disparities in QCA coverage for different ecological metrics highlights the difficulties in relying

499 on MPAs as robust tools for providing multiple types of conservation benefits simultaneously.

500 MPAs may need to be explicitly focused on particular conservation goals rather than being

501 implemented with unrealistic expectations that the can be 'all things for all people'. Indeed, over

502 a decade ago Agardy et al. (2003) cautioned that if MPAs failed to live up to unrealistically high

503 expectations, there could be repercussions for marine conservation if managers were to lose

504 confidence in MPAs as an effective tool in the overall conservation toolkit.

505

506

QCA utility for MPA studies

Set-theoretic methodologies have been used over the past 20 years to identify causal pathways from case conditions to outcomes of interest for a diverse range of social and political phenomena. Increasingly QCA has been applied in other fields such as the health sciences

510 (Candy et al. 2013), public and social policy (Rihoux and Marx 2013), and environmental

511 management (Basurto 2013; Huntjens et al. 2011; Never and Betz 2014; Robinson et al. 2014;

512 Rudel 2008; Sutton and Rudd 2015). If used in conjunction with statistical and qualitative

513 research, set-theoretic methods also have potential to help bridge the quantitative and qualitative

514 research worlds (Brady and Collier 2004; Goertz and Mahoney 2012; Rihoux 2003). 
While beyond the scope of the current study, it would be possible to delve more deeply

516

517

518

519

520

521

522

523

524

525

526

527

528

529

530

531

532

533

534

535

536 537

into context at MPAs that have been flagged as having potentially anomalous performance given

their NEOLI configuration and develop hypotheses about which additional conditions, if empirically present, may or may not lead to outcomes of interest. Individual cases identified as logical remainders or contradictions in QCA can provide rich insights to help interpret Boolean solutions and can complement statistical analyses even in large- $n$ studies (Glaesser and Cooper 2011) by helping advance theoretical insights on determinants of MPA success. They can also provide direction for future sampling strategies - for example, it would seem to make sense for set theoretic analyses to have more sites that combined ecological isolation with various combinations of the other NEOLI conditions (recall Figure 3) or to identify MPAs that, if they exist, did not have exhibit of the NEOLI conditions.

In addition to identifying potential case studies of research interest, QCA encourages substantive thinking about counterfactuals. In this study, for example, simply assuming that all remainders for ecologically isolated MPAs would result in High biomass (equation 1.P) is likely simplistic (given three empirical instances with the configuration neOlI did not result in High biomass). However, simply taking the complex model with its assumptions regarding a total lack of successful outcomes irrespective of conditions exhibited by the configurations with less than two empirical observations (equation 1.C) is somewhat naïve given two of the remainders involved combinations of four of the five NEOLI conditions. As all logical remainders and excluded cases lacked ecologically isolation (recall Figure 3), it seems more plausible that parsimonious models are justifiable but this is an issue that could be explored in more depth (and may suggest strategic future sampling for additional Reef Life surveys). 
538

539

540

541

542

543

544

545

546

547

548

549

550

551

552

553

554

555

556

557

558

559

560

\section{Conclusions}

There is a need for reflection on the design, governance, and management determinants of MPA success so that marine conservation investments can achieve the best possible ecological and socio-economic outcomes. Edgar et al. (2014) used the Reef Life Survey dataset to conduct a global analysis of MPA ecological performance and concluded that the conservation benefits of MPAs increased exponentially with the accumulation of the five NEOLI features. Halpern (2014), in the accompanying Nature editorial, argued that "It is clear that designating and enforcing park boundaries, although necessary, is not sufficient to gain full conservation benefits, and that protected areas without all five features should not be expected to produce such benefits" (p. 168). In this set theoretic analysis, results clearly showed that the presence of all five NEOLI were not needed to produce ecological benefits and that, when considering the five NEOLI conditions, only $20 \%$ to $30 \%$ of cases with positive ecological outcomes were explained. The 'bad news' from this analysis was that set theoretic QCA does not support the view that accumulation of ecological benefits was exponential from three NEOLI conditions.

There is, however, a 'good news' story here as well. One of the NEOLI conditions ecological isolation - was overwhelmingly the most important condition in the variety of configurations that led to positive MPA outcomes and, even more so, provided protection against adverse outcomes for large, mobile species of commercial (and recreational) importance. As Halpern (2014) highlighted, it is difficult to achieve all five conditions. The results here showed that isolation alone or in combination with only one or two other conditions may help achieve key MPA objectives, a positive development given recent announcements of large and isolated MPAs being approved internationally (e.g., in the Pitcairn Islands and Chile's NazcaDesventuradas Marine Park). The importance of ecological isolation may also help focus 
561 deliberations for future MPA site selection and suggests caution regarding opportunistic

562 designation of MPAs based on factors related solely to managerial convenience.

563 As Halpern (2014) further emphasized, "more research is needed to better understand the

564 generality of the authors' [Edgar et al.] results, and how other factors could influence

565 conservation success" (p.168). The relatively low coverage of NEOLI pathways to positive

566 ecological outcomes suggests that there are indeed factors other than NEOLI conditions that

567 have an important impact on MPA success. For researchers, this points to the pressing need to

568 further expand the scope of research on the determinants of MPA success so as to identify and

569 account for ecological and human-oriented conditions that, in combination, help achieve

570 recovery and protection targets across a broad range of MPA configurations. 


\section{Acknowledgements}

573 I thank Graham Edgar for supplying data and Mahmoud Sarhan for exploratory research

574 during his MSc research at University of York.

575

576

577

578 
579

580

581

582

583

584

585

586

587

588

589

590

591

592

593

594

595

596

597

598

599

600

601

\section{Literature cited}

Agardy T, Bridgewater P, Crosby MP, Day J, Dayton PK, Kenchington R, Laffoley D, McConney P, Murray PA, Parks JE et al. 2003. Dangerous targets? Unresolved issues and ideological clashes around marine protected areas. Aquatic Conservation: Marine and Freshwater Ecosystems 13:353-367. DOI: 10.1002/aqc.583

Allison GW, Gaines SD, Lubchenco J, Possingham HP. 2003. Ensuring persistence of marine reserves: catastrophes require adapting an insurance factor. Ecological Applications 13:S8-S24. DOI: 10.1890/1051-0761(2003)013[0008:EPOMRC]2.0.CO;2

Basurto X. 2013. Linking multi-level governance to local common-pool resource theory using fuzzy-set qualitative comparative analysis: insights from twenty years of biodiversity conservation in Costa Rica. Global Environmental Change 22:573-587. DOI: 10.1016/j.gloenvcha.2013.02.011

Bodin Ö, Österblom H. 2013. International fisheries regime effectiveness - activities and resources of key actors in the Southern Ocean. Global Environmental Change 23:948956. DOI: 10.1016/j.gloenvcha.2013.07.014

Brady HE, Collier DW, editors. 2004. Rethinking Social Inquiry. Boulder, Colorado: Rowman and Littlefield.

Brown K, Adger WN, Tompkins E, Bacon P, Shim D, Young K. 2001. Trade-off analysis for marine protected area management. Ecological Economics 37:417-434. DOI: $10.1016 / \mathrm{S} 0921-8009(00) 00293-7$

Candy B, King M, Jones L, Oliver S. 2013. Using qualitative evidence on patients' views to help understand variation in effectiveness of complex interventions: a qualitative comparative analysis. Trials 14:179. DOI: 10.1186/1745-6215-14-179 
602 Crawford B, Kasmidi M, Korompis F, Pollnac RB. 2006. Factors influencing progress in 603 establishing community-based marine protected areas in Indonesia. Coastal Management 604 34:39-64. DOI: 10.1080/08920750500379300

605

606

607

608

609

610

611

612

613

614

615

616

617

618

619

620

621

622

623

Edgar GJ, Stuart-Smith RD. 2009. Ecological effects of marine protected areas on rocky reef communities; a continental-scale analysis. Marine Ecology Progress Series 388: 51-62. DOI: $10.3354 / \operatorname{meps} 08149$

Edgar GJ, Stuart-Smith RD, Willis TJ, Kininmonth S, Baker SC, Banks S, Barrett NS, Becerro MA, Bernard AT, Berkhout J. 2014. Global conservation outcomes depend on marine protected areas with five key features. Nature 506:216-220. DOI: 10.1038/nature13022

Gell F, Roberts CM. 2003. The fishery effects of marine reserves and fishery closures. Trends in Ecology and Evolution 18:448-455. DOI: 10.1016/S0169-5347(03)00189-7

Glaesser J, Cooper B. 2011. Selecting cases for in-depth study from a survey dataset: an application of Ragin's configurational methods. Methodological Innovations Online 6:5270. DOI: $10.4256 /$ mio. 2010.0035

Goertz G, Mahoney J. 2012. A Tale of Two Cultures: Qualitative and Quantitative Research in the Social Sciences. Princeton, New Jersey: Princeton University Press.

Guidetti P, Sala E. 2007. Community-wide effects of marine reserves in the Mediterranean Sea. Marine Ecology Progress Series 335:43-56. DOI: 10.3354/meps 335043

Gutiérrez NL, Hilborn R, Defeo O. 2011. Leadership, social capital and incentives promote successful fisheries. Nature 470:386-389. DOI: 10.1038/nature09689

Halpern BS. 2014. Making marine protected areas work. Nature 506:167-168. DOI: 10.1038 /nature13053 
624 Halpern BS, Warner RR. 2002. Marine reserves have rapid and lasting effects. Ecology Letters

625

626

627

628

629

630

632

633

634

635

636

637

638

639

640

641

642

643

644

645

5:361-366. DOI: 10.1046/j.1461-0248.2002.00326.x

Huijbers CM, Connolly RM, Pitt KA, Schoeman DS, Schlacher TA, Burfeind DD, Steele C, Olds AD, Maxwell PS, Babcock RC et al. In press. Conservation benefits of marine reserves are undiminished near coastal rivers and cities. Conservation Letters: 10.1111/conl.12128.

Huntjens P, Pahl-Wostl C, Rihoux B, Schlüter M, Flachner Z, Neto S, Koskova R, Dickens C, Nabide Kiti I. 2011. Adaptive water management and policy learning in a changing climate: a formal comparative analysis of eight water management regimes in Europe, Africa and Asia. Environmental Policy and Governance 21:145-163. DOI:

10.1002/eet.571

Jones PJS. 2002. Marine protected area strategies: issues, divergences and the search for middle ground. Reviews in Fish Biology and Fisheries 11:197-216. DOI:

10.1023/A:1020327007975

Kosamu IBM. 2015. Conditions for sustainability of small-scale fisheries in developing countries. Fisheries Research 161:365-373. DOI: 10.1016/j.fishres.2014.09.002

Lester SE, Halpern BS, Grorud-Colvert K, Lubchenco J, Ruttenberg BI, Gaines SD, Airamé S, Warner RR. 2009. Biological effects within no-take marine reserves: a global synthesis. Marine Ecology Progress Series 384:33-46. DOI: 10.3354/meps08029

Lubchenco J, Palumbi SR, Gaines SD and Andelman S. 2003. Plugging a hole in the ocean: the emerging science of marine reserves. Ecological Applications 13(1 Supplement):S3-S7. DOI: 10.1890/1051-0761(2003)013[0003:PAHITO]2.0.CO;2 
646 MacNeil MA, Graham NAJ, Cinner JE, Wilson SK, Williams ID, Maina J, Newman S, 647 Friedlander AM, Jupiter S, Polunin NVC, McClanahan TR. 2015. Recovery potential of

648

649

650

651

652

653

654

655

656

657

658

659

660

661

662

663

664

665

666

667 the world's coral reef fishes. Nature 520: 341-344. DOI: $10.1038 /$ nature14358

Never B, Betz J. 2014. Comparing the climate policy performance of emerging economies. World Development 59:1-15. DOI: 10.1016/j.worlddev.2014.01.016

Parsons ECM, Favaro B, Aguirre AA, Bauer AL, Blight LK, Cigliano JA, Coleman MA, Côté IM, Draheim M, Fletcher S et al. 2014. Seventy-one important questions for the conservation of marine biodiversity. Conservation Biology 28:1206-1214. DOI: 10.1111/cobi.12303

Pollnac RB, Crawford BR, Gorospe MLG. 2001. Discovering factors that influence the success of community-based marine protected areas in the Visayas, Philippines. Ocean \& Coastal Management 44:683-710. DOI: 10.1016/S0964-5691(01)00075-8

Ragin CC. 1987. The Comparative Method: Moving Beyond Qualitative and Quantitative Strategies. Berkeley, California: University of California Press.

Ragin CC. 2000. Fuzzy-Set Social Science. Chicago: University of Chicago Press.

Ragin CC, Davey S. 2014. Fuzzy-Set/Qualitative Comparative Analysis 2.5. Irvine, California: Department of Sociology, University of California.

Rihoux B. 2003. Bridging the gap between the qualitative and quantitative worlds? A retrospective and prospective view on Qualitative Comparative Analysis. Field Methods 15:351-365. DOI: $10.1177 / 1525822 \times 03257690$

Rihoux B. 2013. Qualitative Comparative Analysis (QCA): reframing the comparative method's seminal statements. Swiss Political Science Review 19:233-245. DOI: 10.1111/spsr.12031 
668 Rihoux B, Marx A. 2013. QCA, 25 years after “The Comparative Method”: mapping, 669 challenges, and innovations - mini-symposium. Political Research Quarterly 66:167-235. DOI: $10.1177 / 1065912912468269$

671

672

673

674

675

676

677

678

679

680

681

682

683

684

685

686

687

688

Roberts CM. 1997. Ecological advice for the global fisheries crisis. Trends in Ecology and Evolution 12:35-38. DOI: 10.1016/S0169-5347(96)20109-0

Robinson BE, Holland MB, Naughton-Treves L. 2014. Does secure land tenure save forests? A meta-analysis of the relationship between land tenure and tropical deforestation. Global Environmental Change 27:281-293. DOI: dx.doi.org/10.1016/j.gloenvcha.2013.05.012

Rudd MA. 2014. Scientists' perspectives on global ocean research priorities. Frontiers in Marine Science 1:36. DOI: 10.3389/fmars.2014.00036.

Rudd MA, Tupper MH, Folmer H, van Kooten GC. 2003. Policy analysis for tropical marine reserves: directions and challenges. Fish and Fisheries 4:65-85. DOI: 10.1046/j.14672979.2003.00110.x

Rudel TK. 2008. Meta-analyses of case studies: a method for studying regional and global environmental change. Global Environmental Change 18:18-25. DOI: 10.1016/j.gloenvcha.2007.06.001

Schneider CQ and Wagemann C. 2012. Set-Theoretic Methods for the Social Sciences: A Guide to Qualitative Comparative Analysis. Cambridge, U.K.: Cambridge University Press.

Soykan CU, Lewison RL. 2015. Using community-level metrics to monitor the effects of marine protected areas on biodiversity. Conservation Biology 29: 775-783. DOI: 10.1111/cobi. 12445 
689 Stokke OS. 2007. Qualitative comparative analysis, shaming, and international regime

$690 \quad$ effectiveness. Journal of Business Research 60:501-511. DOI:

691 10.1016/j.jbusres.2007.01.003

692

693

694

695

696

697

698

699

700

701

702

703

704

705

706

707

708

709

710

711

Sumaila UR, Guenette S, Alder J, Chuenpagdee R. 2000. Addressing ecosystem effects of fishing using marine protected areas. ICES Journal of Marine Science 57:752-760. DOI: 10.1006/jmsc. 2000.0732

Sutton AM, Rudd MA. 2015. The effect of leadership and other contextual conditions on the ecological and socio-economic success of small-scale fisheries in Southeast Asia. Ocean \& Coastal Management 114:102-115. DOI: 10.1016/j.ocecoaman.2015.06.009

Thiem A, Duşa A. 2013. Boolean minimization in social science research: a review of current software for Qualitative Comparative Analysis (QCA). Social Science Computer Review 31:505-521. DOI: $10.1177 / 0894439313478999$

Vandeperre F, Higgins RM, Sánchez-Meca J, Maynou F, Goñi R, Martín-Sosa P, Pérez-Ruzafa A, Afonso P, Bertocci I, Crec'hriou R et al. 2011. Effects of no-take area size and age of marine protected areas on fisheries yields: a meta-analytical approach. Fish and Fisheries 12:412-426. DOI: 10.1111/j.1467-2979.2010.00401.x

Warner TE, Pomeroy RS. 2012. Paths of influence: the direct and indirect determinants of Marine Managed Area success. Coastal Management 40:250-267. DOI: $10.1080 / 08920753.2012 .677630$

Weigel J-Y, Mannle KO, Bennett NJ, Carter E, Westlund L, Burgener V, Hoffman Z, Simão Da Silva A, Kane EA, Sanders J et al. 2014. Marine protected areas and fisheries: bridging the divide. Aquatic Conservation: Marine and Freshwater Ecosystems 24(S2):199-215. DOI: 10.1002 aqc. 2514 
712 White JW, Botsford LW, Baskett ML, Barnett LAK, Barr RJ, Hastings A. 2011. Linking models

713 with monitoring data for assessing performance of no-take marine reserves. Frontiers in

714 Ecology and the Environment 9:390-399. DOI: 10.1890/100138 


\section{Table 1 (on next page)}

Number of MPAs belonging to NEOLI condition sets 


\begin{tabular}{|c|c|c|c|c|c|c|}
\hline \multirow[b]{2}{*}{ Condition } & \multicolumn{3}{|c|}{ Edgar et al. coding } & \multicolumn{2}{|l|}{ Crisp sets } & \multirow[b]{2}{*}{ Comments } \\
\hline & Low & Med & High & Fully Out & Fully In & \\
\hline No-take & 0 & 46 & 75 & 46 & 75 & $\begin{array}{l}\text { Referred to as governance or regulations by Edgar } \\
\text { et al. (2014): low=openly fished; med=within MPA } \\
\text { but with some fishing; high=no-take zone within } \\
\text { MPA }\end{array}$ \\
\hline Enforced & 12 & 27 & 82 & 39 & 82 & $\begin{array}{l}\text { Assessed by field survey teams (Edgar et al., 2014) } \\
\text { low='paper park' with little control; med=moderate } \\
\text { policing but with violations; high==well-enforced }\end{array}$ \\
\hline Old & 19 & 38 & 64 & 57 & 64 & Low $=<5$ yrs; Med $=5-10$ yrs; High $>10$ yrs \\
\hline Large & 24 & 56 & 41 & 80 & 41 & Low $=<1 \mathrm{~km}^{2} ;$ Med $=1-100 \mathrm{~km}^{2} ; \mathrm{High}>100 \mathrm{~km}^{2}$ \\
\hline Isolated & 79 & 18 & 24 & 97 & 24 & $\begin{array}{l}\text { Low=shallow reef habitat continuous across MPA } \\
\text { boundary; Med=small }(1-20 \%) \text { of zone boundary } \\
\text { breached by shallow reef habitat; High }>\text { MPA zone } \\
\text { isolated from fishing zone by depth or sand barriers }\end{array}$ \\
\hline
\end{tabular}

1 


\section{Table 2 (on next page)}

Summary of outcome set calibrations

* Values in parentheses denote cut-off and cross-over biomass and species richness values prior to $\ln (n+1)$ transformation 


\begin{tabular}{|c|c|c|c|c|c|c|c|}
\hline \multirow[b]{2}{*}{ Outcome sets } & \multirow[b]{2}{*}{ Min } & \multirow[b]{2}{*}{ Mean } & \multirow[b]{2}{*}{$\operatorname{Max}$} & \multicolumn{3}{|c|}{ Fuzzy membership calibration } & \multirow[b]{2}{*}{$\ln (n+1)\left(\right.$ per $\left.250 \mathrm{~m}^{2}\right)$} \\
\hline & & & & Fully out & Crossover & Fully in & \\
\hline High biomass & 4.07 & 9.78 & 12.38 & $\begin{array}{l}7.5 \\
(1808)^{*}\end{array}$ & $\begin{array}{l}9.6 \\
(14765)\end{array}$ & $\begin{array}{l}11.7 \\
(120572)\end{array}$ & total fish biomass [g] \\
\hline $\begin{array}{l}\text { High large fish } \\
\text { biomass }\end{array}$ & 3.11 & 8.54 & 11.79 & $\begin{array}{l}5.5 \\
(245)\end{array}$ & $\begin{array}{l}8.1 \\
(3295)\end{array}$ & $\begin{array}{l}10.7 \\
(44356)\end{array}$ & total biomass $[\mathrm{g}]$ of large fish \\
\hline $\begin{array}{l}\text { High damselfish } \\
\text { biomass }\end{array}$ & 0.00 & 6.46 & 11.05 & $\begin{array}{l}3.5 \\
(33)\end{array}$ & $\begin{array}{l}6.4 \\
(602)\end{array}$ & $\begin{array}{l}9.3 \\
(10938)\end{array}$ & total biomass $[\mathrm{g}]$ of damselfish \\
\hline $\begin{array}{l}\text { High grouper } \\
\text { biomass }\end{array}$ & 0.00 & 3.36 & 8.74 & $\begin{array}{l}1.0 \\
(3)\end{array}$ & $\begin{array}{l}4.5 \\
(90)\end{array}$ & $\begin{array}{l}8.0 \\
(2981)\end{array}$ & total biomass $[\mathrm{g}]$ of groupers \\
\hline $\begin{array}{l}\text { High jack } \\
\text { biomass }\end{array}$ & 0.00 & 3.89 & 10.93 & $\begin{array}{l}3.0 \\
(20)\end{array}$ & $\begin{array}{l}6.3 \\
(518)\end{array}$ & $\begin{array}{l}9.5 \\
(13360)\end{array}$ & total biomass $[\mathrm{g}]$ of jacks \\
\hline $\begin{array}{l}\text { High shark } \\
\text { biomass }\end{array}$ & 0.00 & 2.78 & 11.06 & $\begin{array}{l}0.7 \\
(2)\end{array}$ & $\begin{array}{l}5.1 \\
(164)\end{array}$ & $\begin{array}{l}9.5 \\
(13360)\end{array}$ & total biomass $[\mathrm{g}]$ of sharks \\
\hline $\begin{array}{l}\text { High fish species } \\
\text { richness }\end{array}$ & 0.77 & 2.79 & 4.12 & $\begin{array}{l}1.5 \\
(5)\end{array}$ & $\begin{array}{l}2.7 \\
(14)\end{array}$ & $\begin{array}{l}3.8 \\
(45)\end{array}$ & all fish species \\
\hline $\begin{array}{l}\text { High large fish } \\
\text { species richness }\end{array}$ & 0.04 & 1.27 & 2.39 & $\begin{array}{l}0.2 \\
(1)\end{array}$ & $\begin{array}{l}1.1 \\
(3)\end{array}$ & $\begin{array}{l}1.9 \\
(7)\end{array}$ & large fish $[>300 \mathrm{~mm}]$ species \\
\hline
\end{tabular}

* values in parentheses denote cut-off and cross-over biomass (g per $250 \mathrm{~m}^{2}$ ) and species richness values

2 prior to $\ln (n+1)$ transformation

3

4 
Table 3 (on next page)

Case study condition and outcome coding 


\begin{tabular}{|c|c|c|c|c|c|c|c|c|c|c|c|c|c|c|}
\hline & & Mem & ersh & in $\mathrm{co}$ & ditio & & Level & of $\mathbf{m e}$ & bershi & in the & set of: & & & \\
\hline & Country & 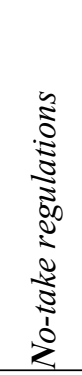 & 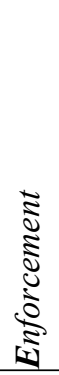 & $\begin{array}{l}8 \\
8 \\
0 \\
0\end{array}$ & 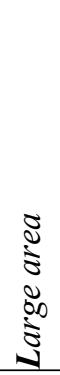 & 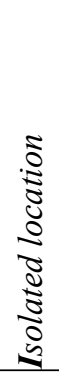 & 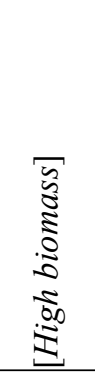 & 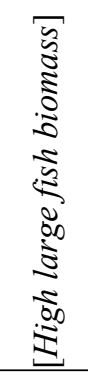 & 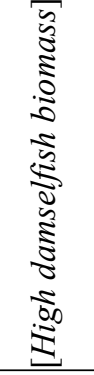 & 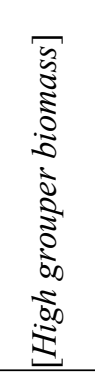 & 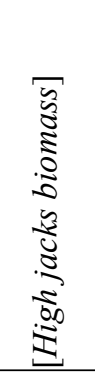 & 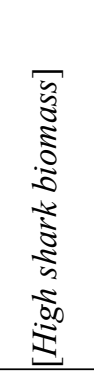 & 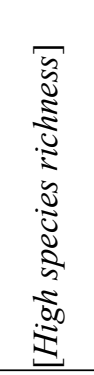 & 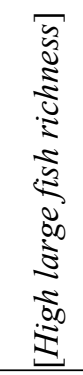 \\
\hline 15. Cocos National Park & Costa Rica & 1 & 1 & 1 & 1 & 1 & 0.98 & 1.00 & 0.78 & 0.80 & 0.91 & 1.00 & 0.74 & 1.00 \\
\hline 34. Kermadec Marine Reserve & New Zealand & 1 & 1 & 1 & 1 & 1 & 0.99 & 1.00 & 0.98 & 0.93 & 0.77 & 1.00 & 0.60 & 0.95 \\
\hline 37. Lord Howe Commonwealth MPA a & Australia & 1 & 1 & 1 & 1 & 1 & 0.78 & 0.96 & 0.78 & 0.95 & 0.70 & 1.00 & 0.75 & 0.91 \\
\hline 40. Malpelo Flora and Fauna Sanctuary & Colombia & 1 & 1 & 1 & 1 & 1 & 0.99 & 1.00 & 0.89 & 1.00 & 0.76 & 1.00 & 0.64 & 0.93 \\
\hline 20. Florida Keys National Marine Sanctuary b & United States & 1 & 1 & 1 & 1 & 0 & 0.73 & 0.68 & 0.76 & 0.69 & 0.89 & 0.00 & 0.71 & 0.85 \\
\hline 72. Tsitsikamma National Park & South Africa & 1 & 1 & 1 & 1 & 0 & 0.65 & 0.62 & 0.00 & 0.58 & 0.00 & 0.00 & 0.33 & 0.69 \\
\hline 52. Poor Knights Island Marine Reserve & New Zealand & 1 & 1 & 1 & 0 & 1 & 0.65 & 0.71 & 1.00 & 0.00 & 0.79 & 0.00 & 0.39 & 0.73 \\
\hline 63. Shiprock Aquatic Reserve & Australia & 1 & 1 & 1 & 0 & 1 & 0.88 & 0.88 & 0.52 & 0.73 & 0.86 & 0.00 & 0.90 & 1.00 \\
\hline 1. Aldinga Reef & Australia & 1 & 1 & 1 & 0 & 0 & 0.40 & 0.63 & 0.23 & 0.00 & 0.00 & 0.00 & 0.44 & 0.56 \\
\hline 11. Cape Rodney to Okakari Point Marine Reserve & New Zealand & 1 & 1 & 1 & 0 & 0 & 0.47 & 0.66 & 0.17 & 0.00 & 0.82 & 0.00 & 0.19 & 0.53 \\
\hline 12. Cathedral Cove Marine Reserve & New Zealand & 1 & 1 & 1 & 0 & 0 & 0.64 & 0.83 & 0.31 & 0.00 & 0.91 & 0.00 & 0.26 & 0.60 \\
\hline 19. Florida Keys National Marine Sanctuary a & USA & 1 & 1 & 1 & 0 & 0 & 0.91 & 0.89 & 0.82 & 1.00 & 0.42 & 0.00 & 0.85 & 1.00 \\
\hline 21. Fly Point-Halifax Park & Australia & 1 & 1 & 1 & 0 & 0 & 0.63 & 0.77 & 0.41 & 0.64 & 0.49 & 0.68 & 0.72 & 0.80 \\
\hline 26. Governor Island Marine Nature Reserve & Australia & 1 & 1 & 1 & 0 & 0 & 0.00 & 0.25 & 0.00 & 0.00 & 0.00 & 0.00 & 0.00 & 0.42 \\
\hline 29. Hanauma Bay Marine Life Conservation District & USA & 1 & 1 & 1 & 0 & 0 & 0.52 & 0.46 & 0.43 & 0.00 & 0.36 & 0.00 & 0.76 & 0.77 \\
\hline 35. La Restinga-Mar de las Calmas MPA & Spain & 1 & 1 & 1 & 0 & 0 & 0.57 & 0.71 & 0.59 & 0.87 & 0.47 & 0.00 & 0.42 & 0.99 \\
\hline 36. La Reserve Naturelle Marine de Cerb re Banyuls & France & 1 & 1 & 1 & 0 & 0 & 0.38 & 0.49 & 0.58 & 0.50 & 0.00 & 0.00 & 0.39 & 0.44 \\
\hline 38. Lord Howe Island Marine Park a & Australia & 1 & 1 & 1 & 0 & 0 & 0.80 & 0.96 & 0.93 & 0.55 & 0.69 & 0.87 & 0.69 & 0.65 \\
\hline 41. Maria Island Marine Reserve & Australia & 1 & 1 & 1 & 0 & 0 & 0.29 & 0.51 & 0.00 & 0.00 & 0.29 & 0.40 & 0.25 & 0.58 \\
\hline 42. Marmion Marine Park a & Australia & 1 & 1 & 1 & 0 & 0 & 0.32 & 0.38 & 0.63 & 0.00 & 0.00 & 0.00 & 0.53 & 0.70 \\
\hline 45. Mushi Mas Mingili Thila & Maldives & 1 & 1 & 1 & 0 & 0 & 0.84 & 0.88 & 0.41 & 0.00 & 0.93 & 0.00 & 1.00 & 0.98 \\
\hline 47. Ningaloo Marine Park a & Australia & 1 & 1 & 1 & 0 & 0 & 0.60 & 0.52 & 0.84 & 0.65 & 0.00 & 0.00 & 0.85 & 0.38 \\
\hline 48. Ningaloo Marine Park b & Australia & 1 & 1 & 1 & 0 & 0 & 0.64 & 0.68 & 0.78 & 0.82 & 0.73 & 0.00 & 0.91 & 0.82 \\
\hline 54. Port Noarlunga Reef & Australia & 1 & 1 & 1 & 0 & 0 & 0.47 & 0.69 & 0.52 & 0.00 & 0.00 & 0.00 & 0.57 & 1.00 \\
\hline 59. Rose Atoll National Wildlife Refuge & American Samoa & 1 & 1 & 1 & 0 & 0 & 0.62 & 0.46 & 0.39 & 0.56 & 0.26 & 0.00 & 0.83 & 0.51 \\
\hline 66. Sund Rock Marine Preserve & USA & 1 & 1 & 1 & 0 & 0 & 0.18 & 0.29 & 0.00 & 0.00 & 0.00 & 0.00 & 0.24 & 0.36 \\
\hline 73. Tuhua/Mayor Island marine reserve & New Zealand & 1 & 1 & 1 & 0 & 0 & 0.66 & 0.79 & 0.89 & 0.00 & 0.85 & 0.71 & 0.39 & 0.88 \\
\hline 74. Tulamben & Indonesia & 1 & 1 & 1 & 0 & 0 & 0.65 & 0.70 & 0.97 & 0.50 & 0.49 & 0.00 & 1.00 & 0.89 \\
\hline
\end{tabular}




\begin{tabular}{|c|c|c|c|c|c|c|c|c|c|c|c|c|c|c|}
\hline 27. Great Barrier Reef MP a & Australia & 1 & 1 & $\overline{0}$ & 1 & 0 & 0.67 & 0.67 & 0.99 & 0.78 & 0.61 & 0.65 & 0.93 & 0.63 \\
\hline 33. Kent Group Marine Park a & Australia & 1 & 1 & 0 & 1 & 0 & 0.59 & 0.51 & 0.53 & 0.00 & 0.00 & 0.50 & 0.37 & 0.66 \\
\hline 4. Beware Reef Marine Sanctuary & Australia & 1 & 1 & 0 & 0 & 1 & 0.78 & 0.74 & 0.69 & 0.00 & 0.38 & 0.71 & 0.47 & 0.92 \\
\hline 70. Te Paepae o Aotea Marine Reserve & New Zealand & 1 & 1 & 0 & 0 & 1 & 1.00 & 1.00 & 1.00 & 0.00 & 0.30 & 0.00 & 0.33 & 0.81 \\
\hline 3. Batemans Marine Park a & Australia & 1 & 1 & 0 & 0 & 0 & 0.74 & 0.73 & 0.96 & 0.45 & 1.00 & 0.72 & 0.49 & 0.86 \\
\hline 5. Bushrangers Bay Aquatic Reserve & Australia & 1 & 1 & 0 & 0 & 0 & 0.44 & 0.55 & 0.84 & 0.00 & 0.00 & 0.00 & 0.59 & 0.62 \\
\hline 6. Cabbage Tree Bay Aquatic Reserve & Australia & 1 & 1 & 0 & 0 & 0 & 0.73 & 0.73 & 0.60 & 0.19 & 0.90 & 0.73 & 0.74 & 0.77 \\
\hline 9. Cape Byron Marine Park & Australia & 1 & 1 & 0 & 0 & 0 & 0.88 & 0.98 & 0.84 & 0.60 & 0.64 & 0.86 & 0.86 & 1.00 \\
\hline 10. Cape Howe Marine National Park & Australia & 1 & 1 & 0 & 0 & 0 & 0.78 & 0.68 & 0.58 & 0.00 & 1.00 & 0.78 & 0.50 & 0.93 \\
\hline 13. Channel Islands National Marine Sanctuary a & USA & 1 & 1 & 0 & 0 & 0 & 0.33 & 0.58 & 0.00 & 0.00 & 0.00 & 0.00 & 0.30 & 0.65 \\
\hline 14. Channel Islands National Marine Sanctuary b & USA & 1 & 1 & 0 & 0 & 0 & 0.58 & 0.67 & 0.98 & 0.00 & 0.00 & 0.11 & 0.43 & 0.81 \\
\hline 23. Galapagos Marine Reserve b & Ecuador & 1 & 1 & 0 & 0 & 0 & 1.00 & 1.00 & 0.64 & 0.77 & 0.68 & 1.00 & 0.74 & 1.00 \\
\hline 28. Great Barrier Reef MP b & Australia & 1 & 1 & 0 & 0 & 0 & 0.63 & 0.70 & 0.87 & 0.82 & 0.76 & 0.00 & 1.00 & 0.88 \\
\hline 31. Jervis Bay a & Australia & 1 & 1 & 0 & 0 & 0 & 0.81 & 0.71 & 0.72 & 0.09 & 1.00 & 0.81 & 0.66 & 0.79 \\
\hline 32. Jurien Bay a & Australia & 1 & 1 & 0 & 0 & 0 & 0.39 & 0.54 & 0.79 & 0.51 & 0.00 & 0.00 & 0.47 & 0.60 \\
\hline 50. Point Cooke Marine Sanctuary & Australia & 1 & 1 & 0 & 0 & 0 & 0.00 & 0.00 & 0.00 & 0.00 & 0.00 & 0.00 & 0.00 & 0.00 \\
\hline 51. Point Lobos State Marine Reserve & USA & 1 & 1 & 0 & 0 & 0 & 0.16 & 0.47 & 0.00 & 0.00 & 0.00 & 0.00 & 0.25 & 0.70 \\
\hline 53. Port Davey National Park a & Australia & 1 & 1 & 0 & 0 & 0 & 0.00 & 0.07 & 0.00 & 0.00 & 0.00 & 0.42 & 0.00 & 0.17 \\
\hline 55. Port Phillip Heads Marine National Park & Australia & 1 & 1 & 0 & 0 & 0 & 0.44 & 0.66 & 0.60 & 0.00 & 0.00 & 0.72 & 0.30 & 0.68 \\
\hline 56. Port Stephens Great Lake Marine Park a & Australia & 1 & 1 & 0 & 0 & 0 & 0.71 & 0.57 & 0.69 & 0.25 & 1.00 & 0.68 & 0.67 & 0.70 \\
\hline 58. Rickett's Point Marine Sanctuary & Australia & 1 & 1 & 0 & 0 & 0 & 0.00 & 0.12 & 0.00 & 0.00 & 0.00 & 0.00 & 0.00 & 0.12 \\
\hline 60. Rottnest Island a & Australia & 1 & 1 & 0 & 0 & 0 & 0.65 & 0.80 & 0.65 & 0.39 & 0.29 & 0.42 & 0.56 & 0.67 \\
\hline 65. Solitary Islands Marine Park a & Australia & 1 & 1 & 0 & 0 & 0 & 0.88 & 1.00 & 0.94 & 0.74 & 0.88 & 1.00 & 0.69 & 0.70 \\
\hline 71. Tinderbox Marine Reserve & Australia & 1 & 1 & 0 & 0 & 0 & 0.21 & 0.39 & 0.00 & 0.00 & 0.00 & 0.00 & 0.23 & 0.47 \\
\hline 17. Ponta da Baleia-Abrolhos a & Brazil & 1 & 0 & 1 & 1 & 0 & 0.62 & 0.61 & 0.81 & 0.63 & 0.00 & 0.00 & 0.61 & 0.67 \\
\hline 25. Golfo de Chiriqui Marine National Park & Panama & 1 & 0 & 1 & 1 & 0 & 0.33 & 0.13 & 0.72 & 0.85 & 0.44 & 0.00 & 0.57 & 0.17 \\
\hline 43. Mnazi Bay-Ruvuma Estuary Marine Park & Tanzania & 1 & 0 & 1 & 1 & 0 & 0.59 & 0.34 & 0.78 & 0.67 & 0.00 & 0.00 & 1.00 & 0.70 \\
\hline 2. Baie Ternay & Seychelles & 1 & 0 & 1 & 0 & 0 & 0.71 & 0.65 & 0.56 & 0.53 & 0.00 & 0.00 & 0.98 & 0.80 \\
\hline 30. Isla de Taboga e Isla de Uraba Wildlife Refuge & Panama & 1 & 0 & 1 & 0 & 0 & 0.49 & 0.63 & 0.68 & 0.86 & 0.00 & 0.00 & 0.59 & 0.73 \\
\hline 39. Machalilla & Ecuador & 1 & 0 & 1 & 0 & 0 & 0.45 & 0.52 & 0.79 & 0.84 & 0.00 & 0.00 & 0.64 & 0.67 \\
\hline 49. Pangaimotu Reef MPA & Tonga & 1 & 0 & 1 & 0 & 0 & 0.38 & 0.40 & 0.77 & 0.94 & 0.00 & 0.00 & 0.90 & 0.12 \\
\hline 62. Sesoko Scientific Research Area & Japan & 1 & 0 & 1 & 0 & 0 & 0.57 & 0.00 & 0.79 & 0.32 & 0.00 & 0.00 & 0.97 & 0.12 \\
\hline 64. Shiraiwazaki Marine Park & Japan & 1 & 0 & 1 & 0 & 0 & 0.12 & 0.04 & 0.00 & 0.61 & 0.00 & 0.00 & 0.62 & 0.12 \\
\hline 67. Table Mountain National Park a & South Africa & 1 & 0 & 1 & 0 & 0 & 0.59 & 0.53 & 0.00 & 0.00 & 0.03 & 0.45 & 0.23 & 0.52 \\
\hline 68. Tawharanui Marine Reserve & New Zealand & 1 & 0 & 1 & 0 & 0 & 0.17 & 0.46 & 0.00 & 0.00 & 0.43 & 0.00 & 0.06 & 0.36 \\
\hline 75. Ushibuka Marine Park & Japan & 1 & 0 & 1 & 0 & 0 & 0.40 & 0.24 & 0.57 & 0.75 & 0.00 & 0.00 & 0.66 & 0.29 \\
\hline 16. Coiba National Park a & Panama & 1 & 0 & 0 & 1 & 1 & 0.76 & 0.85 & 0.80 & 0.91 & 0.85 & 0.57 & 0.69 & 0.71 \\
\hline 44. Motu Motiro Hiva & Chile & 1 & 0 & 0 & 1 & 1 & 0.65 & 0.62 & 0.59 & 0.00 & 0.36 & 0.85 & 0.50 & 0.53 \\
\hline 7. Caletas & Costa Rica & 1 & 0 & 0 & 1 & 0 & 0.13 & 0.00 & 0.45 & 0.66 & 0.00 & 0.00 & 0.42 & 0.00 \\
\hline 8. Camaronal & Costa Rica & 1 & 0 & 0 & 1 & 0 & 0.06 & 0.12 & 0.56 & 0.62 & 0.00 & 0.00 & 0.39 & 0.00 \\
\hline
\end{tabular}




\begin{tabular}{|c|c|c|c|c|c|c|c|c|c|c|c|c|c|c|}
\hline 18. Fiordo Comau Protected Area & Chile & 1 & 0 & $\overline{0}$ & 0 & 0 & 0.33 & 0.52 & 0.00 & 0.00 & 0.00 & 0.00 & 0.00 & 0.32 \\
\hline 22. Galapagos Marine Reserve a & Ecuador & 1 & 0 & 0 & 0 & 0 & 1.00 & 1.00 & 0.98 & 1.00 & 0.77 & 1.00 & 0.74 & 1.00 \\
\hline 24. Galapagos Marine Reserve c & Ecuador & 1 & 0 & 0 & 0 & 0 & 1.00 & 0.98 & 0.89 & 1.00 & 0.00 & 0.48 & 0.55 & 1.00 \\
\hline 46. Ninepin Point Marine Reserve & Australia & 1 & 0 & 0 & 0 & 0 & 0.36 & 0.37 & 0.00 & 0.00 & 0.00 & 0.00 & 0.15 & 0.28 \\
\hline 57. Regno di Nettuno a & Italy & 1 & 0 & 0 & 0 & 0 & 0.24 & 0.00 & 0.70 & 0.00 & 0.00 & 0.00 & 0.38 & 0.01 \\
\hline 61. Seaflower Area Marina Protegida a & Colombia & 1 & 0 & 0 & 0 & 0 & 0.59 & 0.57 & 0.59 & 0.70 & 0.44 & 0.00 & 0.77 & 0.63 \\
\hline 69. Te Matuku Marine Reserve & New Zealand & 1 & 0 & 0 & 0 & 0 & 0.00 & 0.00 & 0.00 & 0.00 & 0.00 & 0.00 & 0.00 & 0.00 \\
\hline 101. Lord Howe Commonwealth MPA b & Australia & 0 & 1 & 1 & 1 & 1 & 0.75 & 0.85 & 0.82 & 1.00 & 0.69 & 0.88 & 0.75 & 0.88 \\
\hline 80. Channel Islands National Marine Sanctuary c & USA & 0 & 1 & 1 & 1 & 0 & 0.29 & 0.44 & 0.35 & 0.00 & 0.00 & 0.00 & 0.44 & 0.69 \\
\hline 81. Channel Islands National Marine Sanctuary d & USA & 0 & 1 & 1 & 1 & 0 & 0.56 & 0.42 & 1.00 & 0.00 & 0.00 & 0.00 & 0.41 & 0.57 \\
\hline 86. Florida Keys National Marine Sanctuary c & USA & 0 & 1 & 1 & 1 & 0 & 0.61 & 0.55 & 0.73 & 0.62 & 0.40 & 0.00 & 0.76 & 0.59 \\
\hline 104. Ningaloo Marine Park c & Australia & 0 & 1 & 1 & 1 & 0 & 0.74 & 0.55 & 0.80 & 0.77 & 0.00 & 0.70 & 0.94 & 0.70 \\
\hline 105. Ningaloo Marine Park d & Australia & 0 & 1 & 1 & 1 & 0 & 0.69 & 0.76 & 0.82 & 0.68 & 0.03 & 0.77 & 0.88 & 0.63 \\
\hline 78. Bonaire & Netherlands Antilles & 0 & 1 & 1 & 0 & 1 & 0.56 & 0.56 & 0.91 & 0.48 & 0.33 & 0.00 & 0.84 & 0.90 \\
\hline 87. Fly Point-Halifax Park & Australia & 0 & 1 & 1 & 0 & 0 & 0.39 & 0.46 & 0.29 & 0.33 & 0.00 & 0.54 & 0.72 & 0.55 \\
\hline 102. Lord Howe Island Marine Park b & Australia & 0 & 1 & 1 & 0 & 0 & 0.66 & 0.79 & 0.93 & 0.07 & 0.43 & 0.78 & 0.62 & 0.59 \\
\hline 103. Marmion Marine Park b & Australia & 0 & 1 & 1 & 0 & 0 & 0.74 & 0.92 & 0.70 & 0.36 & 0.17 & 0.00 & 0.48 & 0.64 \\
\hline 106. North Sydney Harbour Aquatic Reserve & Australia & 0 & 1 & 1 & 0 & 0 & 0.64 & 0.69 & 0.81 & 0.00 & 0.85 & 0.29 & 0.66 & 0.66 \\
\hline 114. Rottnest Island c & Australia & 0 & 1 & 1 & 0 & 0 & 0.56 & 0.68 & 0.73 & 0.40 & 0.43 & 0.70 & 0.55 & 0.68 \\
\hline 116. Shoalwater Islands Marine Park & Australia & 0 & 1 & 1 & 0 & 0 & 0.41 & 0.57 & 0.45 & 0.00 & 0.00 & 0.00 & 0.31 & 0.30 \\
\hline 118. St. Abbs and Eyemouth Marine Reserve & Scotland & 0 & 1 & 1 & 0 & 0 & 0.05 & 0.31 & 0.00 & 0.00 & 0.00 & 0.00 & 0.07 & 0.27 \\
\hline 89. Galapagos Marine Reserve e & Ecuador & 0 & 1 & 0 & 1 & 1 & 0.88 & 0.97 & 0.78 & 0.89 & 0.45 & 0.92 & 0.67 & 1.00 \\
\hline 112. Rose Atoll National Monument & American Samoa & 0 & 1 & 0 & 1 & 1 & 0.66 & 0.58 & 0.49 & 0.47 & 0.70 & 0.00 & 0.85 & 0.71 \\
\hline 76. Batemans Marine Park b & Australia & 0 & 1 & 0 & 1 & 0 & 0.74 & 0.77 & 0.90 & 0.18 & 0.99 & 0.78 & 0.49 & 0.85 \\
\hline 91. Great Barrier Reef MP c & Australia & 0 & 1 & 0 & 1 & 0 & 0.64 & 0.63 & 0.92 & 0.58 & 0.26 & 0.64 & 0.91 & 0.47 \\
\hline 94. Jervis Bay b & Australia & 0 & 1 & 0 & 1 & 0 & 0.78 & 0.73 & 0.94 & 0.00 & 1.00 & 0.88 & 0.60 & 0.72 \\
\hline 95. Jurien Bay b & Australia & 0 & 1 & 0 & 1 & 0 & 0.43 & 0.65 & 0.71 & 0.40 & 0.41 & 0.00 & 0.43 & 0.63 \\
\hline 97. Kent Group Marine Park b & Australia & 0 & 1 & 0 & 1 & 0 & 0.53 & 0.49 & 0.58 & 0.00 & 0.00 & 0.44 & 0.40 & 0.67 \\
\hline 100. Levante de Mallorca Cala Ratjada & Spain & 0 & 1 & 0 & 1 & 0 & 0.19 & 0.26 & 0.37 & 0.00 & 0.00 & 0.00 & 0.50 & 0.12 \\
\hline 109. Port Stephens Great Lake Marine Park b & Australia & 0 & 1 & 0 & 1 & 0 & 0.92 & 0.75 & 0.88 & 0.24 & 1.00 & 0.85 & 0.62 & 0.74 \\
\hline 117. Solitary Islands Marine Park b & Australia & 0 & 1 & 0 & 1 & 0 & 0.70 & 0.74 & 0.87 & 0.19 & 0.56 & 0.76 & 0.55 & 0.49 \\
\hline 93. Illa del Toro & Spain & 0 & 1 & 0 & 0 & 1 & 0.54 & 0.54 & 0.95 & 0.74 & 0.00 & 0.00 & 0.48 & 0.73 \\
\hline 79. Bronte-Coogee Aquatic Reserve & Australia & 0 & 1 & 0 & 0 & 0 & 0.55 & 0.55 & 0.67 & 0.00 & 0.62 & 0.00 & 0.63 & 0.64 \\
\hline 92. Great Barrier Reef MP d & Australia & 0 & 1 & 0 & 0 & 0 & 0.58 & 0.50 & 0.81 & 0.71 & 0.00 & 0.00 & 1.00 & 0.70 \\
\hline 108. Port Davey National Park b & Australia & 0 & 1 & 0 & 0 & 0 & 0.01 & 0.22 & 0.00 & 0.00 & 0.04 & 0.37 & 0.00 & 0.32 \\
\hline 110. Pupukea Marine Life Conservation District & USA & 0 & 1 & 0 & 0 & 0 & 0.30 & 0.21 & 0.30 & 0.00 & 0.00 & 0.00 & 0.63 & 0.36 \\
\hline 113. Rottnest Island b & Australia & 0 & 1 & 0 & 0 & 0 & 0.32 & 0.39 & 0.71 & 0.62 & 0.00 & 0.00 & 0.58 & 0.62 \\
\hline 82. Coiba National Park b & Panama & 0 & 0 & 1 & 1 & 1 & 0.85 & 1.00 & 0.71 & 0.94 & 1.00 & 0.80 & 0.65 & 0.73 \\
\hline 84. Coringa-Herald Nature Reserve & Australia & 0 & 0 & 1 & 1 & 1 & 0.61 & 0.77 & 0.66 & 0.63 & 0.48 & 0.90 & 0.98 & 0.66 \\
\hline 85. Ponta da Baleia-Abrolhos b & Brazil & 0 & 0 & 1 & 1 & 0 & 0.56 & 0.59 & 0.66 & 0.00 & 0.17 & 0.00 & 0.61 & 0.63 \\
\hline
\end{tabular}




\begin{tabular}{|c|c|c|c|c|c|c|c|c|c|c|c|c|c|c|}
\hline 119. Strangford Lough Marine Nature Reserve & N Ireland & 0 & 0 & 1 & 1 & 0 & 0.00 & 0.00 & 0.00 & 0.00 & 0.00 & 0.00 & 0.00 & 0.00 \\
\hline 120. Table Mountain National Park b & South Africa & 0 & 0 & 1 & 1 & 0 & 0.41 & 0.07 & 0.00 & 0.00 & 0.52 & 0.00 & 0.10 & 0.21 \\
\hline 77. Beacon Island Reef Observation Area & Australia & 0 & 0 & 1 & 0 & 1 & 0.69 & 0.88 & 0.67 & 0.82 & 0.16 & 0.00 & 0.67 & 0.94 \\
\hline 83. Coral Patches Reef Observation Area & Australia & 0 & 0 & 1 & 0 & 1 & 0.45 & 0.70 & 0.66 & 0.56 & 0.00 & 0.00 & 0.47 & 0.49 \\
\hline 99. Leo Island Reef Observation Area & Australia & 0 & 0 & 1 & 0 & 1 & 0.65 & 0.72 & 0.72 & 0.59 & 0.00 & 0.00 & 0.60 & 0.77 \\
\hline 96. Kawasan Wisata & Indonesia & 0 & 0 & 1 & 0 & 0 & 0.70 & 0.46 & 0.83 & 0.58 & 0.17 & 0.00 & 1.00 & 0.49 \\
\hline 107. Panglima Laut & Indonesia & 0 & 0 & 1 & 0 & 0 & 0.62 & 0.30 & 0.79 & 0.56 & 0.00 & 0.00 & 1.00 & 0.21 \\
\hline 88. Galapagos Marine Reserve d & Ecuador & 0 & 0 & 0 & 1 & 1 & 1.00 & 1.00 & 0.89 & 0.95 & 0.49 & 0.71 & 0.64 & 1.00 \\
\hline 90. Galapagos Marine Reserve f & Ecuador & 0 & 0 & 0 & 1 & 1 & 0.94 & 1.00 & 0.88 & 1.00 & 0.00 & 0.43 & 0.57 & 1.00 \\
\hline 98. Las Perlas Marine Special Management Zone & Panama & 0 & 0 & 0 & 1 & 1 & 0.84 & 0.80 & 0.93 & 0.97 & 0.73 & 0.49 & 0.72 & 0.81 \\
\hline 111. Regno di Nettuno b & Italy & 0 & 0 & 0 & 1 & 0 & 0.15 & 0.00 & 0.67 & 0.00 & 0.00 & 0.00 & 0.41 & 0.01 \\
\hline 121. Wadi El Gemal - Hamata Reserve & Egypt & 0 & 0 & 0 & 1 & 0 & 0.54 & 0.56 & 0.68 & 0.56 & 0.25 & 0.00 & 1.00 & 0.85 \\
\hline 115. Seaflower Area Marina Protegida b & Colombia & 0 & 0 & 0 & 0 & 1 & 0.99 & 0.71 & 0.30 & 0.00 & 0.28 & 0.00 & 0.84 & 0.81 \\
\hline
\end{tabular}




\section{Table 4(on next page)}

Number of empirical observations for each MPA configuration; configurations with no observations (logical remainders) and only one observation (below cut-off for inclusion in QCA model) are noted 


\begin{tabular}{|c|c|c|c|c|c|c|c|}
\hline Configuration & No-take & Enforced & Old & Large & Isolated & Instances & Comments \\
\hline 1 & 1 & 1 & 1 & 1 & 1 & 4 & All 5 NEOLI conditions \\
\hline 2 & 1 & 1 & 1 & 1 & 0 & 2 & 4 NEOLI conditions \\
\hline 3 & 1 & 1 & 1 & 0 & 0 & 20 & 3 NEOLI conditions \\
\hline 4 & 1 & 1 & 1 & 0 & 1 & 2 & 4 NEOLI conditions \\
\hline 5 & 1 & 1 & 0 & 1 & 0 & 2 & 3 NEOLI conditions \\
\hline 6 & 1 & 1 & 0 & 1 & 1 & 0 & Logical remainder \\
\hline 7 & 1 & 1 & 0 & 0 & 0 & 20 & 2 NEOLI conditions \\
\hline 8 & 1 & 1 & 0 & 0 & 1 & 2 & 3 NEOLI conditions \\
\hline 9 & 1 & 0 & 1 & 1 & 0 & 3 & 3 NEOLI conditions \\
\hline 10 & 1 & 0 & 1 & 1 & 1 & 0 & Logical remainder \\
\hline 11 & 1 & 0 & 1 & 0 & 0 & 9 & 2 NEOLI conditions \\
\hline 12 & 1 & 0 & 1 & 0 & 1 & 0 & Logical remainder \\
\hline 13 & 1 & 0 & 0 & 1 & 0 & 2 & 2 NEOLI conditions \\
\hline 14 & 1 & 0 & 0 & 1 & 1 & 2 & 3 NEOLI conditions \\
\hline 15 & 1 & 0 & 0 & 0 & 0 & 7 & 1 NEOLI condition \\
\hline 16 & 1 & 0 & 0 & 0 & 1 & 0 & Logical remainder \\
\hline 17 & 0 & 1 & 1 & 1 & 0 & 5 & 3 NEOLI conditions \\
\hline 18 & 0 & 1 & 1 & 1 & 1 & 1 & Not included in analysis \\
\hline 19 & 0 & 1 & 1 & 0 & 0 & 7 & 2 NEOLI conditions \\
\hline 20 & 0 & 1 & 1 & 0 & 1 & 1 & Not included in analysis \\
\hline 21 & 0 & 1 & 0 & 1 & 0 & 8 & 2 NEOLI conditions \\
\hline 22 & 0 & 1 & 0 & 1 & 1 & 2 & 3 NEOLI conditions \\
\hline 23 & 0 & 1 & 0 & 0 & 0 & 5 & 1 NEOLI condition \\
\hline 24 & 0 & 1 & 0 & 0 & 1 & 1 & Not included in analysis \\
\hline 25 & 0 & 0 & 1 & 1 & 0 & 3 & 2 NEOLI conditions \\
\hline 26 & 0 & 0 & 1 & 1 & 1 & 2 & 3 NEOLI conditions \\
\hline 27 & 0 & 0 & 1 & 0 & 1 & 3 & 2 NEOLI conditions \\
\hline 28 & 0 & 0 & 1 & 0 & 0 & 2 & 1 NEOLI condition \\
\hline 29 & 0 & 0 & 0 & 1 & 1 & 3 & 2 NEOLI conditions \\
\hline 30 & 0 & 0 & 0 & 1 & 0 & 2 & 1 NEOLI condition \\
\hline 31 & 0 & 0 & 0 & 0 & 1 & 1 & Not included in analysis \\
\hline 32 & 0 & 0 & 0 & 0 & 0 & 0 & Logical remainder \\
\hline
\end{tabular}

1 


\section{Table 5 (on next page)}

Tests of necessity for positive and negative ecological outcomes (must be $>=0.90$ to be considered a necessary condition) 


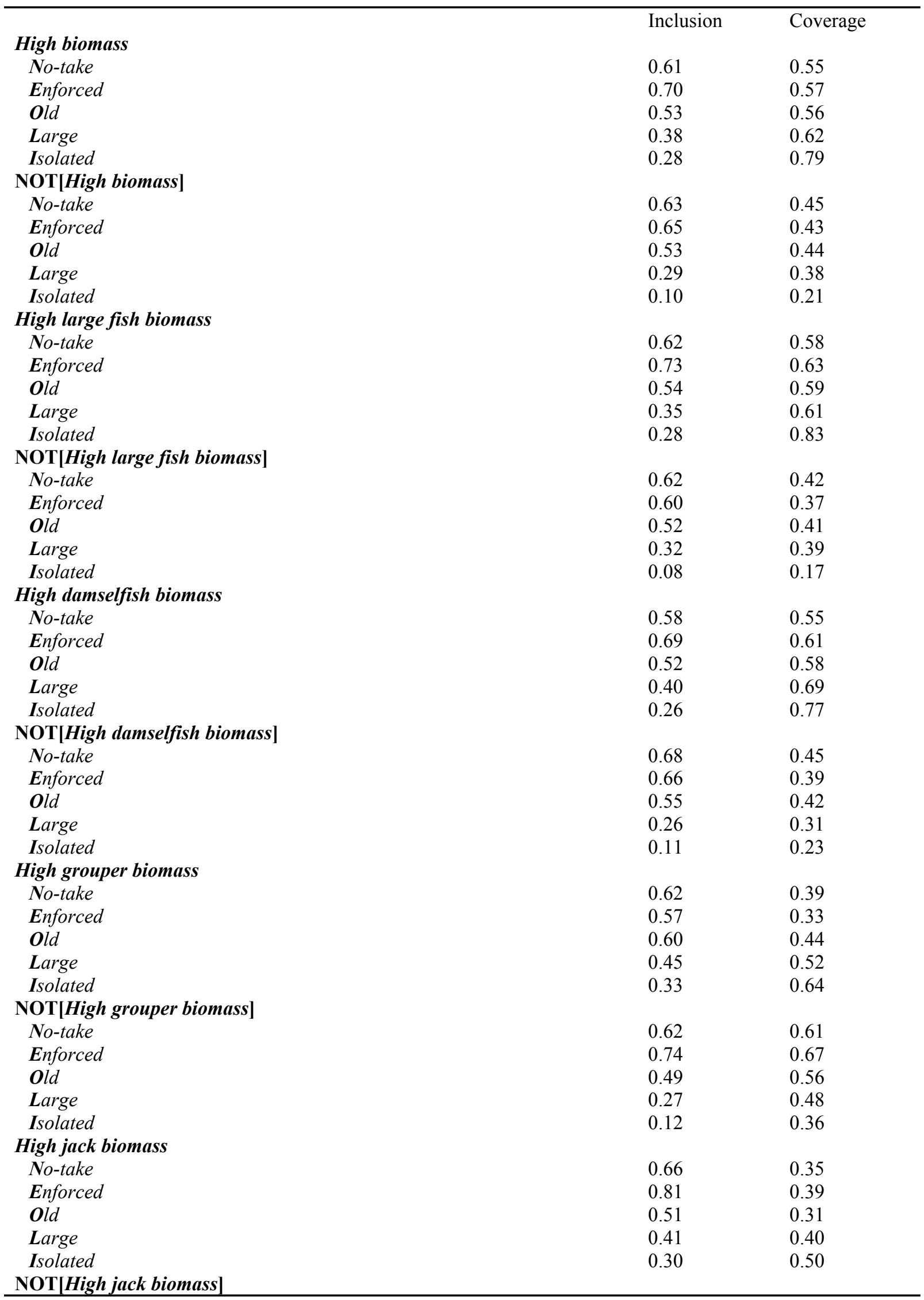




\begin{tabular}{|c|c|c|}
\hline No-take & 0.60 & 0.65 \\
\hline Enforced & 0.61 & 0.61 \\
\hline old & 0.54 & 0.69 \\
\hline Large & 0.30 & 0.60 \\
\hline Isolated & 0.15 & 0.50 \\
\hline \multicolumn{3}{|c|}{ High shark biomass } \\
\hline No-take & 0.60 & 0.27 \\
\hline Enforced & 0.80 & 0.33 \\
\hline Old & 0.40 & 0.21 \\
\hline Large & 0.52 & 0.43 \\
\hline Isolated & 0.33 & 0.47 \\
\hline \multicolumn{3}{|c|}{ NOT[High shark biomass] } \\
\hline No-take & 0.63 & 0.73 \\
\hline Enforced & 0.63 & 0.67 \\
\hline old & 0.58 & 0.79 \\
\hline Large & 0.27 & 0.57 \\
\hline Isolated & 0.15 & 0.53 \\
\hline \multicolumn{3}{|c|}{ High species richness } \\
\hline No-take & 0.59 & 0.54 \\
\hline Enforced & 0.67 & 0.56 \\
\hline old & 0.57 & 0.60 \\
\hline Large & 0.37 & 0.61 \\
\hline Isolated & 0.23 & 0.66 \\
\hline \multicolumn{3}{|c|}{ NOT[High species richness] } \\
\hline No-take & 0.66 & 0.46 \\
\hline Enforced & 0.69 & 0.44 \\
\hline old & 0.48 & 0.40 \\
\hline Large & 0.30 & 0.39 \\
\hline Isolated & 0.16 & 0.34 \\
\hline \multicolumn{3}{|c|}{ High large fish species richness } \\
\hline No-take & 0.63 & 0.62 \\
\hline Enforced & 0.74 & 0.68 \\
\hline Old & 0.53 & 0.62 \\
\hline Large & 0.34 & 0.63 \\
\hline Isolated & 0.27 & 0.83 \\
\hline \multicolumn{3}{|c|}{ NOT[High large fish species richness] } \\
\hline No-take & 0.61 & 0.38 \\
\hline Enforced & 0.57 & 0.32 \\
\hline old & 0.52 & 0.38 \\
\hline Large & 0.33 & 0.37 \\
\hline Isolated & 0.09 & 0.17 \\
\hline
\end{tabular}

1 


\section{Table 6 (on next page)}

High biomass truth table: for MPAs with at least two observations, configuration counts and degree of membership inclusion in the set High biomass 


\begin{tabular}{lllllllll}
\hline Configuration & No-take & Enforced & Old & Large & Isolated & Observed & High biomass & Inclusion \\
\hline 1 & 1 & 1 & 1 & 1 & 1 & 4 & 1 & 0.935 \\
2 & 0 & 0 & 0 & 1 & 1 & 3 & 1 & 0.929 \\
3 & 1 & 1 & 0 & 0 & 1 & 2 & 1 & 0.890 \\
4 & 0 & 1 & 0 & 1 & 1 & 2 & 1 & 0.772 \\
5 & 1 & 1 & 1 & 0 & 1 & 2 & 1 & 0.764 \\
6 & 0 & 0 & 1 & 1 & 1 & 2 & 1 & 0.731 \\
7 & 1 & 0 & 0 & 1 & 1 & 2 & 1 & 0.703 \\
\hline 8 & 1 & 1 & 1 & 1 & 0 & 2 & 0 & 0.692 \\
9 & 0 & 0 & 1 & 0 & 0 & 2 & 0 & 0.663 \\
10 & 1 & 1 & 0 & 1 & 0 & 2 & 0 & 0.629 \\
11 & 0 & 1 & 0 & 1 & 0 & 8 & 0 & 0.617 \\
12 & 0 & 0 & 1 & 0 & 1 & 3 & 0 & 0.596 \\
13 & 0 & 1 & 1 & 1 & 0 & 5 & 0 & 0.578 \\
14 & 1 & 1 & 1 & 0 & 0 & 20 & 0 & 0.530 \\
15 & 1 & 1 & 0 & 0 & 0 & 20 & 0 & 0.518 \\
16 & 1 & 0 & 1 & 1 & 0 & 3 & 0 & 0.513 \\
17 & 1 & 0 & 0 & 0 & 0 & 7 & 0 & 0.501 \\
18 & 0 & 1 & 1 & 0 & 0 & 7 & 0 & 0.492 \\
19 & 1 & 0 & 1 & 0 & 0 & 9 & 0 & 0.430 \\
20 & 0 & 1 & 0 & 0 & 0 & 5 & 0 & 0.353 \\
21 & 0 & 0 & 0 & 1 & 0 & 2 & 0 & 0.344 \\
22 & 0 & 0 & 1 & 1 & 0 & 3 & 0 & 0.324 \\
23 & 1 & 0 & 0 & 1 & 0 & 2 & 0 & 0.098 \\
\hline
\end{tabular}

1 


\section{Table 7 (on next page)}

MPAs with greater than $50 \%$ membership in the sufficient condition High biomass. Italics indicate MPAs not covered in the complex solution but covered under the parsimonious solution 


\begin{tabular}{|c|c|c|c|c|c|c|c|}
\hline \multirow[b]{2}{*}{ Case } & \multicolumn{5}{|c|}{ Complex } & \multicolumn{2}{|c|}{ Parsimonious } \\
\hline & $1 . \mathrm{C} 1$ & 1.C2 & $1 . \mathrm{C} 3$ & 1.C4 & $1 . \mathrm{C} 5$ & 1.P1 & $1 . \mathrm{P} 2$ \\
\hline 4. Beware Reef Marine Sanctuary & & & & 1 & & & 1 \\
\hline 15. Cocos National Park & & & & & 1 & 1 & 1 \\
\hline 16. Coiba National Park $b$ & 1 & & & & & 1 & \\
\hline 34. Kermadec Marine Reserve & & & & & 1 & 1 & 1 \\
\hline 37. Lord Howe Commonwealth MPA $a$ & & & & & 1 & 1 & 1 \\
\hline 40. Malpelo Flora and Fauna Sanctuary & & & & & 1 & 1 & 1 \\
\hline 44. Motu Motiro Hiva & 1 & & & & & 1 & \\
\hline 52. Poor Knights Island Marine Reserve & & & & 1 & 1 & & 1 \\
\hline 63. Shiprock Aquatic Reserve & & & & 1 & 1 & & 1 \\
\hline 70. Te Paepae o Aotea Marine Reserve & & & & 1 & & & 1 \\
\hline 78. Bonaire & & & & & & & 1 \\
\hline 82. Coiba National Park & & & 1 & & & 1 & \\
\hline 84. Coringa-Herald Nature Reserve & & & 1 & & & 1 & \\
\hline 88. Galapagos Marine Reserve $d$ & 1 & 1 & 1 & & & 1 & \\
\hline 89. Galapagos Marine Reserve $e$ & & 1 & & & & 1 & 1 \\
\hline 90. Galapagos Marine Reserve $f$ & 1 & 1 & 1 & & & 1 & \\
\hline 93. Illa del Toro & & & & & & & 1 \\
\hline 98. Las Perlas Marine Special Management Zone & 1 & 1 & 1 & & & 1 & \\
\hline 101. Lord Howe Commonwealth MPA $b$ & & & & & & 1 & 1 \\
\hline 112. Rose Atoll National Monument & & 1 & & & & 1 & 1 \\
\hline
\end{tabular}


Table 8(on next page)

Summary of parsimonious QCA solutions for positive outcomes ( conditions, performance, and total coverage of MPAs by pathway and models)

Upper case/bold denotes presence required; lower case denotes absence required [i.e., NOT set member]; dash denotes condition may be present or absent 


\begin{tabular}{|c|c|c|c|c|c|c|c|c|c|c|c|}
\hline \multirow[b]{2}{*}{ Set / pathways to membership in set } & \multicolumn{5}{|c|}{ MPA NEOLI conditions in sufficient solution } & \multirow[b]{2}{*}{$\begin{array}{l}\text { MPAs } \\
\text { covered }^{a}\end{array}$} & \multicolumn{2}{|c|}{ Model performance } & \multicolumn{2}{|c|}{ Pathway performance } & \multirow[b]{2}{*}{$\begin{array}{l}\text { Pathway } \\
\text { inclusior }\end{array}$} \\
\hline & No-take & Enforced & Old & Large & Isolated & & $\begin{array}{l}\text { Overall } \\
\text { coverage }\end{array}$ & $\begin{array}{l}\text { Overall } \\
\text { inclusion }\end{array}$ & $\begin{array}{l}\text { Raw } \\
\text { coverage }\end{array}$ & $\begin{array}{l}\text { Unique } \\
\text { coverage }\end{array}$ & \\
\hline Model P.1: High biomass & & & & & & 20 & 0.238 & 0.804 & & & \\
\hline Pathway 1 & - & - & - & $L$ & $I$ & 14 & & & 0.173 & 0.084 & 0.835 \\
\hline Pathway 2 & - & $E$ & - & - & $\boldsymbol{I}$ & 13 & & & 0.154 & 0.065 & 0.803 \\
\hline Model P.3: High large fish biomass & & & & & & 20 & 0.280 & 0.827 & & & \\
\hline Pathway 1 & - & - & - & - & $\boldsymbol{I}$ & 20 & & & 0.280 & 0.280 & 0.827 \\
\hline Model P.5: High damselfish biomass & & & & & & 32 & 0.348 & 0.780 & & & \\
\hline Pathway 1 & $N$ & $E$ & - & - & $I$ & 8 & & & 0.093 & 0.093 & 0.831 \\
\hline Pathway 2 & $n$ & $e$ & - & $l$ & $i$ & 2 & & & 0.022 & 0.022 & 0.806 \\
\hline Pathway 3 & $n$ & $e$ & $o$ & - & $I$ & 4 & & & 0.042 & 0.042 & 0.754 \\
\hline Pathway 4 & - & $E$ & $o$ & $L$ & $i$ & 10 & & & 0.107 & 0.021 & 0.769 \\
\hline Pathway 5 & $n$ & $E$ & - & $L$ & $i$ & 13 & & & 0.137 & 0.052 & 0.760 \\
\hline Pathway 6 & $N$ & $e$ & $\boldsymbol{O}$ & $L$ & - & 3 & & & 0.032 & 0.032 & 0.766 \\
\hline Model P.7: High grouper biomass & & & & & & 13 & 0.240 & 0.870 & & & \\
\hline Pathway 1 & - & - & $\boldsymbol{O}$ & $L$ & $I$ & 7 & & & 0.132 & 0.099 & 0.892 \\
\hline Pathway 2 & $n$ & $e$ & - & $L$ & $I$ & 5 & & & 0.095 & 0.062 & 0.897 \\
\hline Pathway 3 & $N$ & $e$ & $\boldsymbol{O}$ & $L$ & - & 3 & & & 0.046 & 0.046 & 0.716 \\
\hline Model P.9: High jacks biomass & & & & & & 10 & 0.183 & 0.729 & & & \\
\hline Pathway 1 & - & - & $\boldsymbol{O}$ & $L$ & $\boldsymbol{I}$ & 7 & & & 0.134 & 0.037 & 0.759 \\
\hline Pathway 2 & $N$ & - & $\boldsymbol{O}$ & - & $I$ & 6 & & & 0.120 & 0.000 & 0.798 \\
\hline Pathway 3 & - & $E$ & $\boldsymbol{O}$ & - & $\boldsymbol{I}$ & 8 & & & 0.146 & 0.008 & 0.726 \\
\hline Model P.11: High shark biomass & & & & & & 9 & 0.237 & 0.890 & & & \\
\hline Pathway 1 & - & - & $\boldsymbol{O}$ & $L$ & $I$ & 7 & & & 0.195 & 0.195 & 0.941 \\
\hline Pathway 2 & $N$ & $e$ & - & - & $I$ & 2 & & & 0.042 & 0.042 & 0.713 \\
\hline Model P.13: High species richness & & & & & & 11 & 0.128 & 0.794 & & & \\
\hline Pathway 1 & $n$ & $e$ & - & $l$ & $i$ & 2 & & & 0.029 & 0.029 & 1.000 \\
\hline Pathway 2 & $n$ & $e$ & $o$ & - & $i$ & 2 & & & 0.021 & 0.021 & 0.705 \\
\hline Pathway 3 & $N$ & $e$ & $\boldsymbol{O}$ & $L$ & $i$ & 3 & & & 0.032 & 0.032 & 0.726 \\
\hline Pathway 4 & - & $E$ & $o$ & $L$ & $I$ & 2 & & & 0.022 & 0.022 & 0.756 \\
\hline Pathway 5 & - & $e$ & $\boldsymbol{O}$ & $L$ & $I$ & 2 & & & 0.024 & 0.024 & 0.818 \\
\hline Model P.15: High large species richness & & & & & & 21 & 0.240 & 0.854 & & & \\
\hline Pathway 1 & - & - & - & $l$ & $\boldsymbol{I}$ & 10 & & & 0.108 & 0.087 & 0.808 \\
\hline Pathway 2 & $n$ & - & $o$ & - & $\boldsymbol{I}$ & 7 & & & 0.081 & 0.060 & 0.867 \\
\hline Pathway 3 & $N$ & $E$ & $\boldsymbol{O}$ & $L$ & - & 6 & & & 0.071 & 0.071 & 0.887 \\
\hline
\end{tabular}


Table 9 (on next page)

Summary of parsimonious QCA model solutions for negated models: conditions, performance, and total coverage of MPAs by pathway and models 
Table 1 Summary of parsimonious QCA model solutions for negated models: conditions, performance, and total coverage of MPAs by pathway

and models

\begin{tabular}{|c|c|c|c|c|c|c|c|c|c|c|c|}
\hline \multirow[b]{2}{*}{ Set / pathways to membership in set } & \multicolumn{5}{|c|}{ MPA NEOLI conditions } & \multirow[b]{2}{*}{$\begin{array}{l}\text { MPAs } \\
\text { covered }\end{array}$} & \multicolumn{2}{|c|}{ Model performance } & \multicolumn{2}{|c|}{ Pathway performance } & \multirow[b]{2}{*}{$\begin{array}{l}\text { Pathway } \\
\text { inclusior }\end{array}$} \\
\hline & No-take & Enforced & Old & Large & Isolated & & $\begin{array}{l}\text { Overall } \\
\text { coverage }\end{array}$ & $\begin{array}{l}\text { Overall } \\
\text { inclusion }\end{array}$ & $\begin{array}{l}\text { Raw } \\
\text { coverage }\end{array}$ & $\begin{array}{l}\text { Unique } \\
\text { coverage }\end{array}$ & \\
\hline NEGATIVE OUTCOMES & & & & & & & & & & & \\
\hline Model P.2: NOT[High biomass] & & & & & & 2 & 0.034 & 0.903 & & & \\
\hline Pathway 1 & $N$ & $e$ & $o$ & $L$ & $i$ & 2 & & & 0.034 & 0.034 & 0.903 \\
\hline Model P.4: NOT[High large fish biomass] & & & & & & 7 & 0.113 & 0.807 & & & \\
\hline Pathway 1 & - & $e$ & $o$ & $L$ & $i$ & 4 & & & 0.066 & 0.038 & 0.829 \\
\hline Pathway 2 & $n$ & $e$ & - & $L$ & $i$ & 5 & & & 0.075 & 0.047 & 0.755 \\
\hline Model P.6: NOT[High damselfish biomass] & & & & & & 3 & 0.048 & 0.781 & & & \\
\hline Pathway 1 & $n$ & $e$ & $\boldsymbol{O}$ & $L$ & $i$ & 3 & & & 0.048 & 0.048 & 0.781 \\
\hline Model P.8: NOT[High grouper biomass] & & & & & & 40 & 0.519 & 0.782 & & & \\
\hline Pathway 1 & $n$ & - & $o$ & - & $i$ & 15 & & & 0.156 & 0.087 & 0.768 \\
\hline Pathway 2 & - & $\boldsymbol{E}$ & $o$ & $l$ & - & 20 & & & 0.286 & 0.233 & 0.755 \\
\hline Pathway 3 & $n$ & $E$ & - & $l$ & - & 14 & & & 0.139 & 0.086 & 0.735 \\
\hline Pathway 4 & $n$ & $e$ & - & $L$ & $i$ & 5 & & & 0.060 & 0.041 & 0.887 \\
\hline Model P.10: NOT[High jack biomass] & & & & & & 42 & 0.542 & 0.864 & & & \\
\hline Pathway 1 & - & $e$ & - & - & $i$ & 20 & & & 0.305 & 0.254 & 0.885 \\
\hline Pathway 2 & $n$ & - & - & $l$ & - & 19 & & & 0.203 & 0.118 & 0.827 \\
\hline Pathway 3 & $n$ & - & $\boldsymbol{O}$ & - & $i$ & 17 & & & 0.170 & 0.056 & 0.814 \\
\hline Model P.12: NOT[High shark biomass] & & & & & & 54 & 0.706 & 0.905 & & & \\
\hline Pathway 1 & - & $e$ & - & - & $i$ & 20 & & & 0.299 & 0.132 & 0.931 \\
\hline Pathway 2 & $n$ & - & $o$ & $l$ & - & 7 & & & 0.076 & 0.076 & 0.947 \\
\hline Pathway 3 & - & - & $\boldsymbol{O}$ & $\boldsymbol{L}$ & $i$ & 13 & & & 0.132 & 0.040 & 0.887 \\
\hline Pathway 4 & - & - & $\boldsymbol{O}$ & $l$ & $I$ & 6 & & & 0.069 & 0.069 & 1.000 \\
\hline Pathway 5 & $N$ & - & $\boldsymbol{O}$ & - & $i$ & 20 & & & 0.354 & 0.199 & 0.909 \\
\hline Model P.14: NOT[High species richness] & & & & & & 3 & 0.044 & 0.765 & & & \\
\hline Pathway 1 & $n$ & $e$ & $\boldsymbol{O}$ & $\boldsymbol{L}$ & $i$ & 3 & & & 0.044 & 0.044 & 0.765 \\
\hline Model P.16: NOT[High large species richness] & & & & & & 5 & 0.090 & 0.831 & & & \\
\hline Pathway 1 & $N$ & $e$ & $o$ & $\boldsymbol{L}$ & $i$ & 2 & & & 0.043 & 0.043 & 1.000 \\
\hline Pathway 2 & $n$ & $e$ & $O$ & $L$ & $i$ & 3 & & & 0.047 & 0.047 & 0.718 \\
\hline
\end{tabular}


1

Parsimonious solution for High Biomass outcomes: (A) solution coverage by each of two pathways sufficient to achieve High Biomass; and (B) specific MPAs that are members of pathways

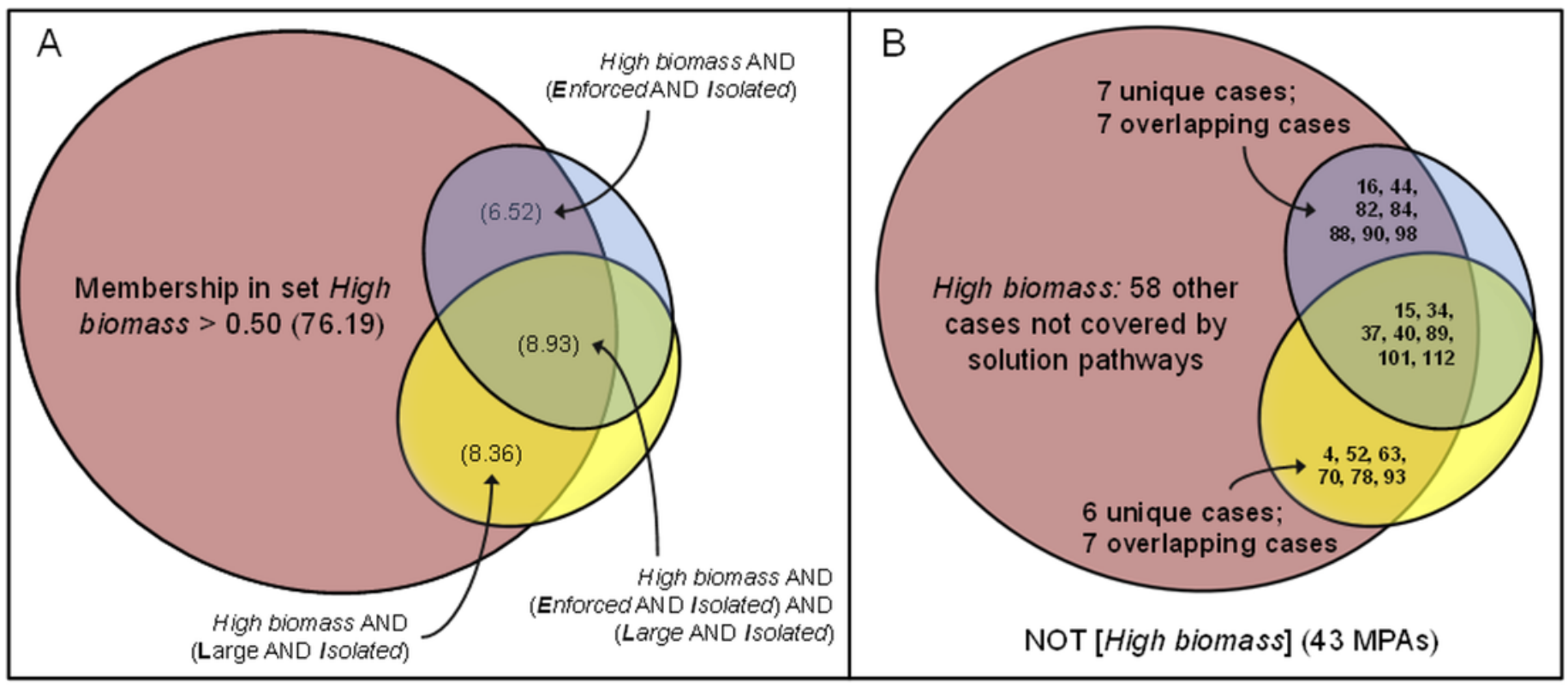


2

Venn diagram of solution coverage for model 2, NOT[High biomass]

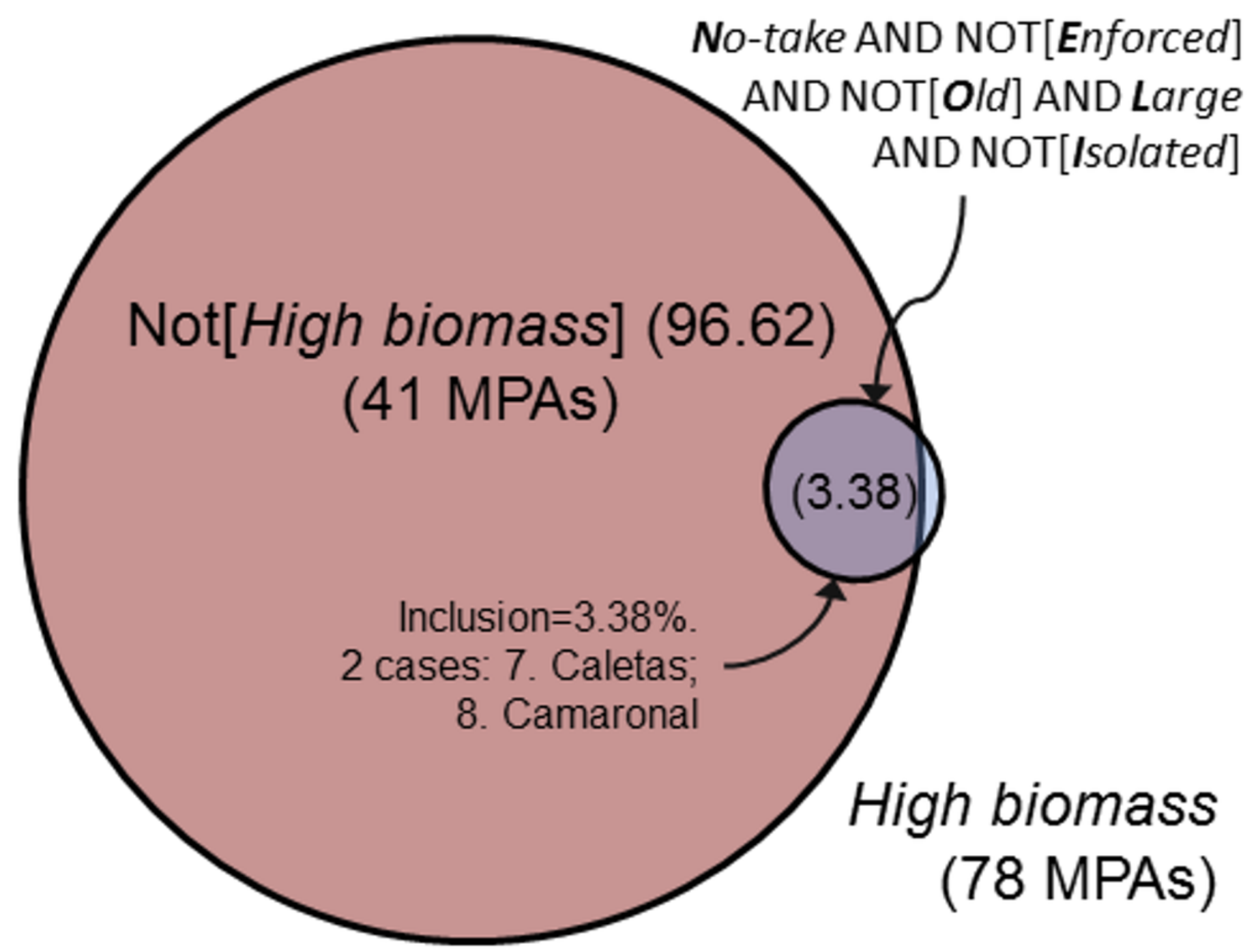




\section{3}

Count of MPAs exhibiting various combinations of conditions

Gray fill indicates configurations that were absent or observed at only a single site in the Reef Life Survey dataset. The colored configurations indicate the difference in times that particular configurations were present in parsimonious solutions less the times they appeared in negative solutions: blue fill indicates top performing MPA configurations (positive minus negative outcomes $=+5,+6$ or +7 ); green $=+2,+3$ or +4 ; yellow $=-1,0$ or +1 ; orange $=-4,-3$ or $-2 ;$ and red $=-5,-6$ or -7 .

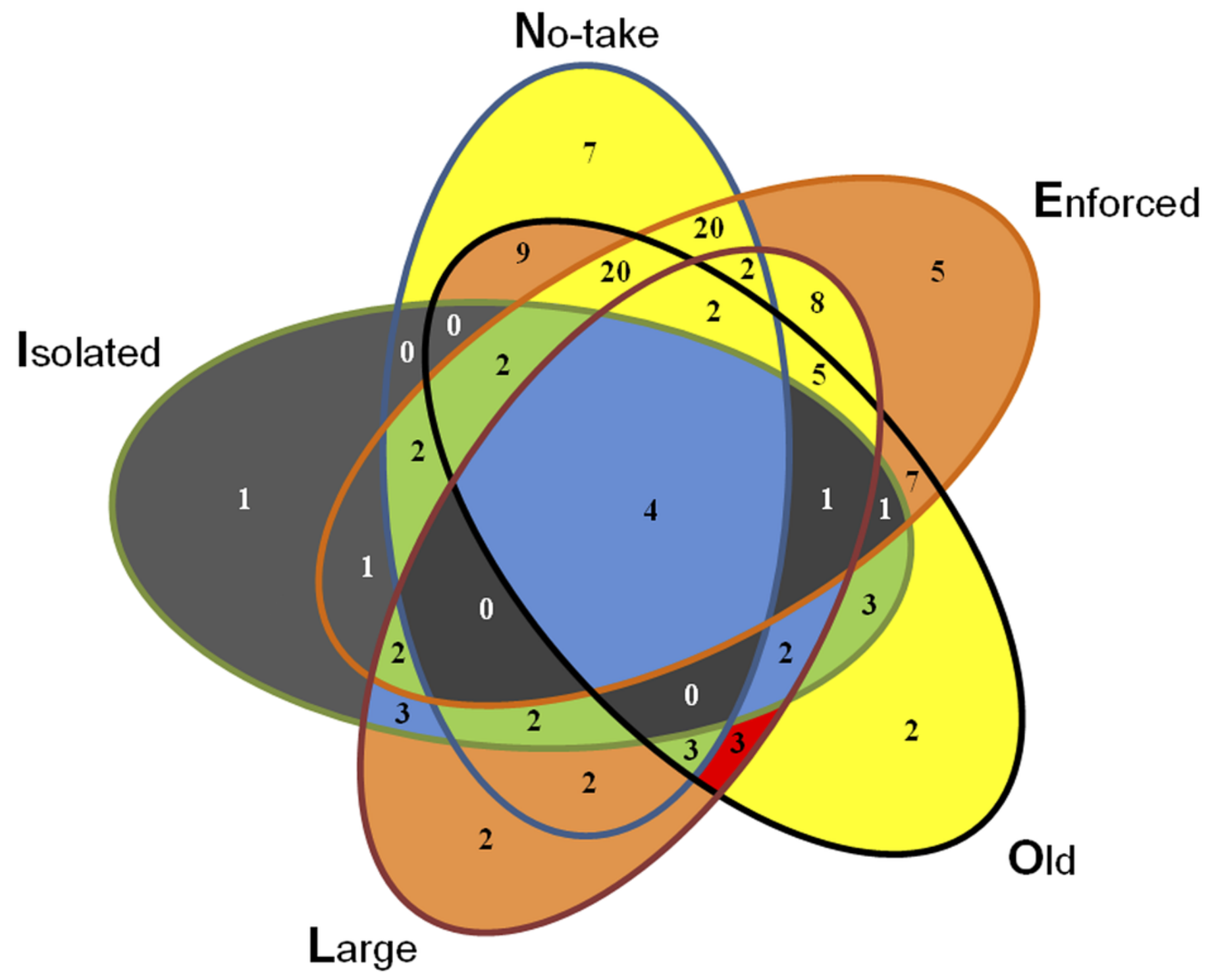

